\title{
The Sahya Mountain: Śiva Religion in the Port Polity of the North Konkan
}

This chapter concludes the project of materializing the Skandapurāna's literary imagining of a Pâsupata landscape by examining the development of Śaiva institutions in the area of the Sahya Mountain (i.e. the North Konkan and the western Deccan), which is the southernmost limit of the authors' map. This region, now occupied by the modern metropolis of Mumbai, is home to three monumental Śaiva religious centers: the cave-temples located on Elephanta Island, the Jogeśvarī caves, and the Maṇdapeśvar caves. These sites are vital material archives for the study of early Śiva religion, mythology, and iconography, yet little is known about their history, the patrons who initiated their construction, and the communities that worshiped within them. In the absence of any dedicatory inscriptions, the challenge of dating these sites has fallen to art historians who, through comparative stylistic analysis with other rock-cut monuments in the region, have approximated the mid-6th to the late 7th century $\mathrm{CE}$ as the period when their construction commenced. It is widely assumed that these cave temples were commissioned by the early Kalacuris, a ruling family active in northwest and central India between the mid-6th and early 7 th century. Despite the popularity of this hypothesis, a critical review of the historical sources offers little with which to tie these rulers to the North Konkan or these three sites. As an alternative scenario, this chapter shows that the growth of early Siva religion in this region was not contingent upon the fortunes of ruling elites; rather, religious institutions were deeply enmeshed in the flourishing trade networks of the cosmopolitan North Konkan coast where they were supported by multiple, corporate patronage networks consisting of merchants, traders, and other local collectives that dominated this port polity.

The chapter begins by introducing the North Konkan's distinct physical geography and situating the Śaiva cave temples within the larger religious, economic, and political topographies of the area. This contextualization reveals significant, yet underappreciated, ties between regional and religious economies, and between the siting of Buddhist and Śaiva religious centers. Next, I address the question of patronage and the roles of political elites in the creation of the North Konkan monuments. In their epigraphic records, the Kalacuris and other rulers of the period adopted the epithet 'paramamāheśvara', 'supremely 
devoted to the Maheśvara' (Śiva). Only rarely, however, do these inscriptions commemorate donations or endowments to Śaiva temples or religious institutions. Rather than allusions to investments in monuments, these epithets functioned as part of a larger, shared discourse of royal power and prestige. Evidence from contemporaneous inscriptions indicates that, prior to the 11th century, the patronage and management of temples was the purview of local communities and merchant collectives, for whom religious giving was part of a repertoire of practices that created new sodalities from among diverse social groups. Echoes of this diversity are materialized in the imagery and spatial articulation of the caves, which display evidence for Pāśupata activity as well as a range of other practices oriented around such deities as Buddhas, bodhisattvas, goddesses, and ganas.

\section{The Sahya Mountain and Śaiva Centers}

Purānic locales are often indicative of a region or direction rather than a specific pinpoint on a map. ${ }^{1}$ For example, I understand the SP authors' use of the phrase 'Sahya Mountain' to mark the southern limit of the Pāśupata landscape as a regional label that refers to the area surrounding the Sahyādri range ${ }^{2}$ - the northern portion of the Western Ghats that divides the North Konkan coast from the Deccan hinterlands. ${ }^{3}$ While the Sahya Mountain resides at the limits of the SP imaginary, the North Konkan and the western Deccan are criti-

1 For example, the SP authors use 'Kārohana' as a heading that refers both to the specific tìrthas where Śiva is incarnated in each yuga and, more broadly, to designate the entire sacred kșetra between the Mahī and the Narmadā rivers. For the literary outline of the Pāśupata landscape in the $\mathrm{SP}_{\mathrm{S}} 110-119$ see Chapter 1.

2 According to Das's survey of traditional geographies, the title 'Sahyādri' refers specifically to the portion of the Western Ghats that extends from the Tapti River south to the Nilgiri Mountains. Hans Bakker notes the reference to Ajanta Cave XVII as the Sahya Mountain in an inscription of Vākāțaka Harișeṇa. Local residents of the Nasik District also refer to the portion of the Ghats in their region as the Sahyādri or Sahya. Dipakranjan Das, Economic History of the Deccan (Delhi: Munshiram Manoharlal, 1967), 8; Hans T. Bakker, The Vākāțakas: An Essay in Hindu Iconology (Groningen: Egbert Forsten, 1997), 35-36.

3 The term 'Deccan,' derived from the Sanskrit dakṣina (right hand/ south), can be taken to refer to the whole of peninsular India south of the Narmadā River or to only the region of the Deccan Plateau. For the purposes of my study, I have focused on the northwest Deccan traditionally called Aśmaka (i.e. the region of the Western Godavari River valley directly connected to the North Konkan via the passes in the Ghats). According to contemporary state divisions, this includes portions of the Nasik, Aurangabad, Pune, and Ahmednagar Districts of Maharashtra. On the history of the use of term Deccan see Das, Economic History of the Deccan, 1-18. 
cally important for the historiography of early Śaivism because some of the earliest surviving monumental Śaiva religious centers-extensive rock-cut cave temple complexes-are located in these regions. The three most important North Konkan sites are incorporated within the metropolis of Mumbai: the cave-temples on Elephanta Island in Mumbai Harbor, the Jogeśvarī caves on Gupha Tekdi in the suburb of Jogeśvarī East, and the Maṇapeśvar caves on Mt. Poinsur in Borivili West. In addition to these coastal sites, the network of Śaiva religious centers extended into the Deccan. ${ }^{4}$ Cave temples were excavated near Aurangabad, Bhokardhan, and the village of Takli-Dhokeśvar in western Maharashtra. ${ }^{5}$

The absence of donative inscriptions from the North Konkan sites, and from contemporaneous sites in the northwest Deccan, has made the attribution of patronage a particularly vexed question. ${ }^{6}$ Despite such significant lacunae in the historical record, it is widely accepted that the North Konkan cave temples were commissioned by the early Kalacuris, a political lineage active in northwest and central India between the mid-6th and early 7 th century.7 The 'Kalacuri hypothesis' was first proposed by the eminent Indian historian V.V. Mirashi and elaborated further by the prolific American art historian Walter Spink in the 1980's. ${ }^{8}$ The pervasive influence of Spink's work is reflected

4 The extent to which the Deccan sites can be classified as 'Śaiva' is addressed in the final sections.

5 The network of caves temples is not restricted to the examples mentioned here. Caves were also excavated near the villages of Mahur and Ter, in Pune, and at Hariścandragad in Maharashtra. Additional monumental sites were established under the patronage of the Cālukya rulers - the religious centers at Bādāmi (the Cālukya capital of Vātāpi), Aihoḷe, Patțadakal, and Siddanakolḷa in addition to another center, Bhairavakondia, to the east of Bādāmi. Since these sites fall outside the geographic scope of this project, they are not discussed here. See EITA 2.1: 276-315. K.V. Soundara Rajan, Architectural Survey of Temples, No. 3: Cave Temples of the Deccan (New Delhi: ASI, 1981), 298-312; Hemanth Kadambi, "Sacred Landscapes in Early Medieval South India: The Chalukya State and Society (AD 550-750)," unpublished dissertation (University of Michigan, 2011).

6 The account of the Portuguese explorer Diogo de Couto (1603) mentions an inscription that was reportedly taken from the Elephanta Caves to be translated. As the removal of the inscription allegedly took place before de Couto's visit to the island, and has not been seen since, its existence is impossible to confirm. De Couto's report is summarized in Maharashtra District Gazetteer, Kolaba District, 785-787. See also Charles Dillard Collins, The Iconography and Ritual of Śiva at Elephanta (Albany: sunY Press, 1988), "Appendix A. Evidence for a Dedication Panel at Elephanta," 151-155.

7 See V.V. Mirashi, CII 4, cxlvii; Walter Spink, "Monuments of the Early Kalacuri Period," Journal of Indian History (1968): 263-70; "The Great Cave at Elephanta: A Study of Sources," in Essays on Gupta Culture, ed. Bardwell L. Smith (Delhi: Motilal Banarsidass, 1983), 238.

8 Spink, "The Great Cave at Elephanta," 257-76; "Bāgh: A Study," Archives of Asian Art 30 (197677):53-84 (55-59);V.V. Mirashi, CII 4, cxlvii. The Konkan Mauryas, and Western Cālukyas have 
throughout the canon of scholarly studies on this region and period, which have echoed his hypothesis and expanded upon it to attribute the construction of Śaiva sites in the Deccan and northwest India to Kalacuri patronage. ${ }^{9}$ Spink has identified the Kalacuri ruler Kṛṣnarāja as the patron of the Konkan monuments since, he argues, the "very grandeur of the Great Cave at Elephanta, which could only have resulted from a vast expenditure of time, labor, and money, suggests that it is a royal monument."10 The excavation of the cave temples did, certainly, require significant economic surplus, not to mention the work of many highly skilled artisans, but the underlying assumption that sponsoring monumental architecture was a practice restricted to ruling elites needs rethinking. As the following pages will show, there is little evidence that places the Kalacuris in the North Konkan during the time the caves were supposedly constructed, nor do their inscriptions mention any such endowments.

Given that it is not based directly upon warranting evidence, I think that the attribution of the North Konkan sites to Kalacuri patronage reflects instead the prevailing historiographical focus on dynastic history and royal personality. ${ }^{11}$

also been suggested as possible patrons of the cave sites, but these theories have been far less popular and influential. Sadashiv Gorakshakar and Karl Khandalavala attribute the Konkan cave temples to the patronage of the Konkan Mauryas. See S. Gorakshakar, "A Harihara Image Recovered from Jogeshwari and the Problem of Dating Gharapuri (Elephanta)," in Madhu: Recent Researches in Indian Archaeology and Art History, ed. M.S. Nagaraja Rao (Delhi: Agam Kala Prakashan, 1981), 247-52; Karl Khandalavala, "Rock-Cut Temples," in Maharashtra, ed. Saryu Doshi (Bombay: Mārg Publications, 1985) K.V. Soundara Rajan connects the caves to Cālukya patronage. Rajan, Cave Temples of the Deccan, Introduction.

9 For evidence of the long-ranging influence of Spink's theories see C.D. Collins, The Iconography and Ritual of Śiva at Elephanta, 4-9; Pia Brancaccio, The Buddhist Caves at Aurangabad (Leiden: E.J. Brill, 2010), 205; Sara L. Schastok, The Śāmalājī Sculptures and 6th Century Art in Western India (Leiden: E.J. Brill, 1985), 44; 96-97; Geri Hockfield Malandara, Unfolding a Mandala: The Buddhist Cave Temples at Ellora (New York: sunY Press, 1993), $5^{-6}$. These studies have extrapolated the influence of the Kalacuris from the North Konkan caves to early stages of building at Ellora, sculpture in Aurangabad, in the Mandasor area of Madhya Pradesh, and at Śāmalājī in Gujarat.

10 Spink, "The Great Cave at Elephanta," 242. In his conclusion, Spink builds upon the previous work of V.V. Mirashi who identifies the Kalacuris as the probable patrons of Elephanta. See Mirashi, CII 4.1, cxlvii-cxlviii. In his work, Mirashi cites a Marathi-language source by Y.R. Gupte (1942).

11 Aside from cautionary remarks, like that of Sara Schastok that the "broader cultural and commercial ties between Mālwā and the corridor to the south should not be overlooked," (The Śamaläjī Sculptures, 97) and the questions raised about Kalacuri patronage in the MA Thesis of Jack C. Laughlin "A Reconsideration of the So-called Kalacuri Monuments of the Deccan and Konkan" (McMaster University, 1993) discussed below, there has been 
This preoccupation has often relegated the activities of other social groups to the margins of scholarly attention. A critical review of the historical sources reveals that the rulers' connection to these sites was tenuous, at best. At the height of their power, the North Konkan occupied the periphery of Kalacuri territory, which was confined to central Mālava and extended only as far as the northwest Deccan, making it unlikely that they ever had direct control over the coast. More importantly, their inscriptions contain no references to the construction of temples or religious monuments; rather, all of their donations were land grants to brahmins recorded on copper-plates. A survey of inscriptions from the North Konkan and the surrounding area shows that during the early medieval period, endowing temples had not yet become a ubiquitous feature of a ruler's religious repertoire. Of the royal inscriptions that do record acts of temple patronage, examples of Śaiva temples are actually quite rare. Epigraphic sources from this particular region indicate that the work of temple building, funding, and maintenance was often a corporate enterprise.

\subsection{The North Konkan Port Polity}

To understand the history of the cave temples requires that we first see them in their geographic context and as an integral part of the North Konkan's port polity-a political entity defined by its coastal commercial networks. An alluvial strip of land, barely $50 \mathrm{~km}$ wide, on India's western coast, the North Konkan (or Aparānta, as it was traditionally known) is bordered by the Arabian Sea on the west, the Sahyādri Mountains on the east, and the Narmadā and Tapti rivers to the north. With the exception of coconut and betel palm, this region is ill suited for agriculture and, from approximately $200 \mathrm{BCE}$, trade has driven the regional economy. ${ }^{12}$

The success of the North Konkan as an exchange center can be attributed to its distinctive terrain. Prior to the efforts of land reclamation initiated by British and Portuguese colonial powers, the coastal area was a cluster of islands dotted with numerous estuaries, littoral ports, and navigable tidal

not been, to my knowledge, a published study that reconsiders the history of these sites. A survey of the secondary literature shows that even when the history of the North Konkan caves is disputed, due to lack of epigraphic or other evidence supporting a particular dynasty as patron, the issue is resolved by ascribing the construction of these monuments to a different ruling family. These patterns are not unique to studies of the North Konkan sites. For an overview of similar patterns in scholarship on Ellora's patronage see Lisa N. Owen, Carving Devotion in the Jain Caves at Ellora (Leiden: Brill, 2012), 160-163.

12 The coconut palm was an important cash crop. Note the inscription from the Nasik Caves about the donation of a grove of coconut trees. Senart, "The Inscriptions at the Caves at Nasik," EI 8 (1905-6): 59-96. 
rivers that extended deep into the interior ${ }^{13}$ [Figure 64]. Many of these littoral ports were small trading posts that serviced local networks, while others, like Sopara, Kalyan, Chaul, Sanjan, and Elephanta, were cosmopolitan centers of long-distance and international exchange. ${ }^{14}$ Analysis of settlement patterns in the region reveals close ties to the regional economy. ${ }^{15}$ Excavations by marine archeologists around Elephanta Island in the late 1990's documented material and numismatic evidence indicative of settlement, commerce, and long-distance exchange from as early as the ist century вСЕ through the 16th century. ${ }^{16}$ Archeologists S. Tripati and A.S. Gaur discovered that the island had three jetties-Mora Bander, Raj Bander, and Shet Bander-that were active at different historical periods as evinced by the range of structural, material, and numismatic evidence. They also noted the remains of an extensive brick wall, now largely submerged in the intertidal zone, which they date to the Gupta Period based upon the dimensions of the bricks used in the construction. Other discoveries of Chinese pottery and Roman amphorae and premodern anchors found submerged around the island, provide further evidence of ship-going trade. Many varieties of copper and silver coins, including Roman, Sātavāhana, Kshatrapa, Traikūṭaka, and Kalacuri issues, were also discovered. ${ }^{17}$

13 On the different varieties of ports in the Konkan see Jean Deloche, "Geographical Consideration in the Localization of Ancient Sea-Ports of India," Indian Economic and Social History Review 20 (1983): 439-448 (especially 441-2); Deloche, La Circulation en Inde, 93. On the ecological history of Mumbai and its wetland environs see Anuradha Mathur \& Dilip de Cunha, Soak: Mumbai in an Estuary (Bombay: Rupa \& Company, 2009).

14 See V.K. Jain, Trade and Traders in Western India (Delhi: Munshiram Manoharlal, 1990), 18. Excavations undertaken at some of these ports provide evidence for international commercial activity and extended periods of habitation. For studies on particular ports see A.K. Ranade: "Contribution of Kalyān to the Cultural Development of Konkan," Studies in Indian Epigraphy 27; Vishwas D. Gogte, "Discovery of the Ancient port of Chaul," Man and Environment 28.1 (2003): 67-74; also on Chaul, Rahul Oka, "Resilience and Adaptation of Trade Networks in East African and South Asian Port Polities," unpublished dissertation (University of Illinois at Chicago, 2008), 30-41. On Sanjan see the series of articles by Ranabir Cakravarti in The Indian Economic and Social History Review (1986, 1990, 1998); Rukshana J. Nanji, Mariner and Merchants: A Study of the Ceramics from Sanjan, Sanjan Reports vol. 1 (BAR International Series, 2011), 8-22.

15 Deloche, "Local of Sea Ports," 442: "Together with the towns in the estuaries at points where the tides carry in the boats, are formed two, sometimes even three degrees of marine penetration. At no other part of the western coast is this parallelism so obvious."

16 S. Tripati and A.S. Gaur, "Onshore and Nearshore Explorations along the Maharashtra Coast: With a View to Locating Ancient Ports and Submerged Sites," Man and Environment 22.2 (1997): 73-83; "Exploration of an Ancient Port: Elephanta Island (Bombay)," in Hemakuta: Recent Researches in Archaeology and Museology, ed. Narasimha A.V. Murthy (Bharatiya Kala Prakashan, 2001), 89-95.

17 Indian Archaeology: A Review (1956-57): 81. 


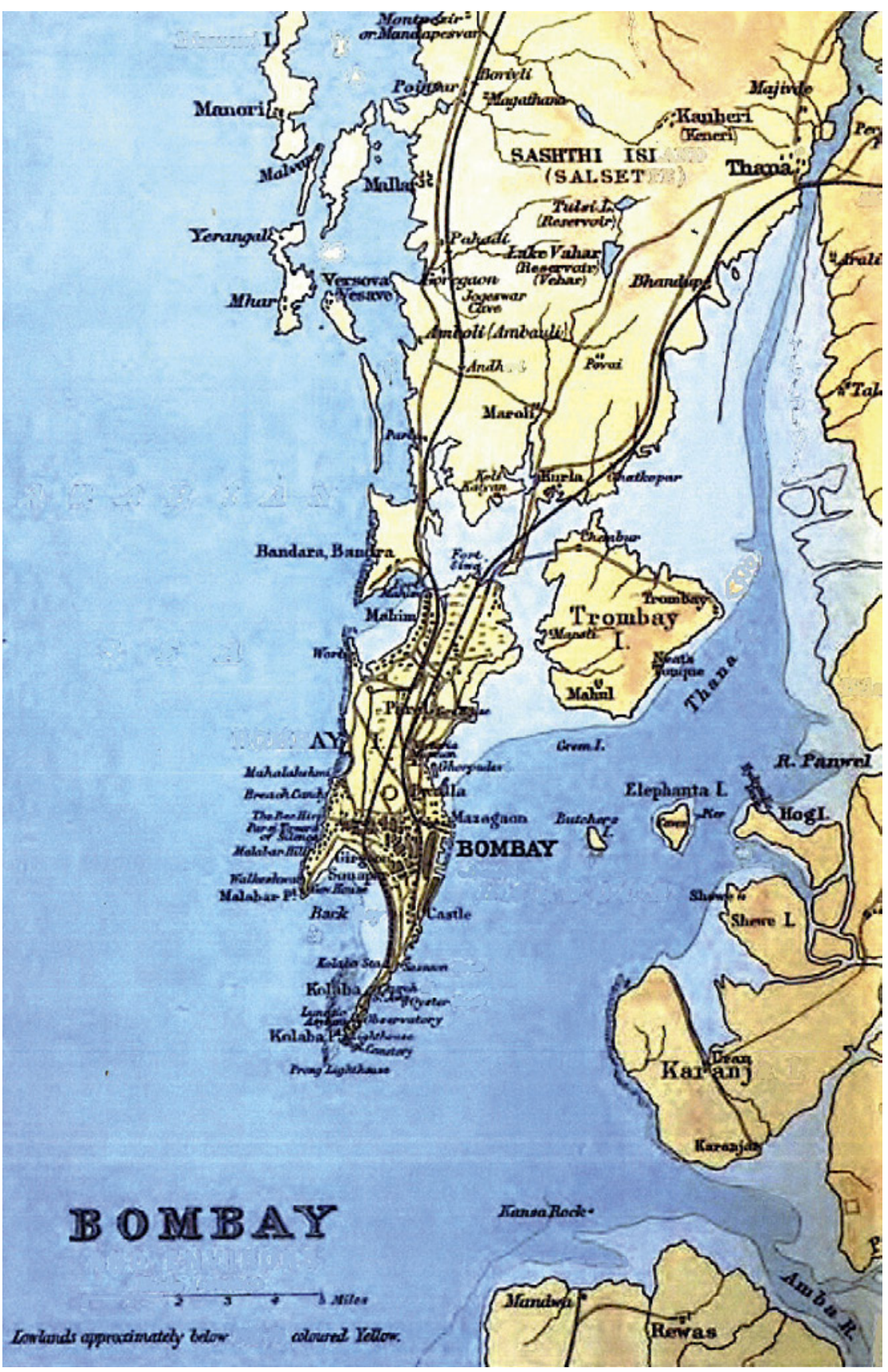

FIGURE 64 Islands of Bombay prior to land reclamation

CONSTABLE'S HAND ATLAS OF INDIA, 1893 EDITION 
Elephanta Island is not a unique case. Ongoing excavations at the nearby port of Sanjan have similarly demonstrated that coastal settlement was oriented around the littoral ports. ${ }^{18}$

Following the pattern of coastal settlement, the growth of sanctified spaces was also conditioned by the distribution of the ports. Prior to the excavation of the Śaiva caves, Buddhist communities had established an extensive network of religious institutions in the region. ${ }^{19}$ In the North Konkan, the patterned siting of Śaiva centers in close proximity to Buddhist caves-both excavated in hills overlooking navigable coastal rivers and in close proximity to littoral ports and centers of trade-created a multi-layered, shared religious landscape suggestive of deep ties to the regional economy. The earliest evidence attesting to this pattern is a group of eleven fragmentary Prakrit inscriptions and symbols dating from the 1st to the 6th century CE engraved around a natural cave at a site called Padana Hill. ${ }^{20}$ Now located within the suburban area of Goregaon, three km west of the Kanheri caves, Padana Hill overlooked the Mithi River, which flows into Mahim Bay. The inscriptions suggest the presence of Vaișnava, Śaiva, and Buddhist practitioners. For example, Inscription $\mathrm{K}$ records the Buddhist creed, Inscription G records the 'step of Rāma', and Inscriptions E and I refer to a religious specialist (siddha) named Musala. ${ }^{21}$ Several sets of footprints engraved in the rock are accompanied by the names of sages. Finally, Inscription C refers to the hill as 'the abode of siddhas' (pavato abhumto sidhavasati / parvatebhyantah siddhavastih) [Figure 65].

18 Rukshana Nanji, Mariners and Merchants: A study of Ceramics from Sanjan (British Archaeological Reports, 2011), 8-22; 212-223.

19 For example, details of the excavation of the settlement mound and Buddhist stūpa at the port of Sopara-dated to approximately 160 в се based on B.L. Indraji's analysis - are summarized in the Gazetteer of the Bombay Presidency, Thana District Revised ed. 1982 (First ed. 1882). On the siting of Buddhist centers such as Kanheri see H.P. Ray, "Early Historical Urbanism: The Case of the Western Deccan," World Archaeology 19.1 (1987): 94104; "Kanheri: the archaeology of an early Buddhist pilgrimage centre in western India," World Archaeology 26.1 (1994): 35-46.

20 H. Lüders, "A List of Brahmi Inscriptions from the Earliest Times to about A.D. 400 with the exception of those of Asoka", EI 10 (1912): 973-983; Bhagavanlal Indraji, "Antiquarian Remains at Sopara and Padana," The Journal of the Bombay Branch of the Royal Asiatic Society 15 (1881-1882): 323-325.

21 Hans Bakker has suggested a possible connection between the name Musala (mentioned in inscriptions E \& I) and the Pāśupata sect called the Mausalas derived from the teachings of Musulendra, who was said to be a pupil of the Pāśupata founder Lakulīśa. H.T. Bakker, "Somaśarman, Somavaṃśa, and Somasiddhānta: A Pāśupata Tradition in Dakșiṇa Kosala, Studies in Skandapurāṇa III," in Harānandalaharī: Volume in Honor of Professor Minoru Hara on his Seventieth Birthday, ed. Ryutaro Tsuchida \& Albrecht Wezler (Reinbek: Dr. Inge Wezler Verlag für Orientalistische Fachpublikationen, 200o), 1-19 (5). 


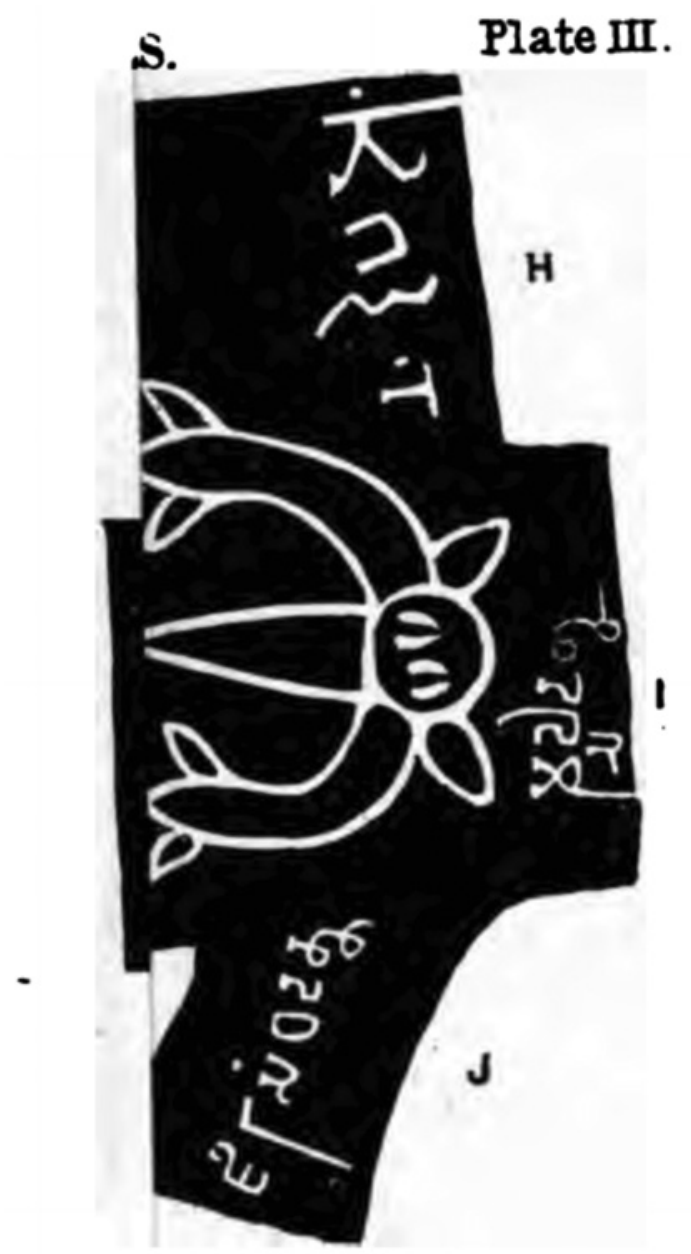

Bha

FIGURE 65 Drawing of inscriptions and symbols from Padana Hill AFTER INDRAJI, 1881

Despite its rather insular geography, the north Konkan maintained ties to the Deccan via three important passes in the Sahyādri Mountains - the Thalghat, Nanaghat, and Bhorghat [Figure 66]. Travel via these passes and routes fostered interregional economic ties between the North Konkan and the agrarian hinterlands of the Deccan, which produced cotton as well as valuable mineral resources and precious stones from its rich 'black cotton' soil. ${ }^{22}$ Via these

22 Rich in nutrients, particularly lime, and extremely moisture retentive, this volcanic soil is excellent for growing cotton as well as wheat, millet, and pulses. Numerous historical 


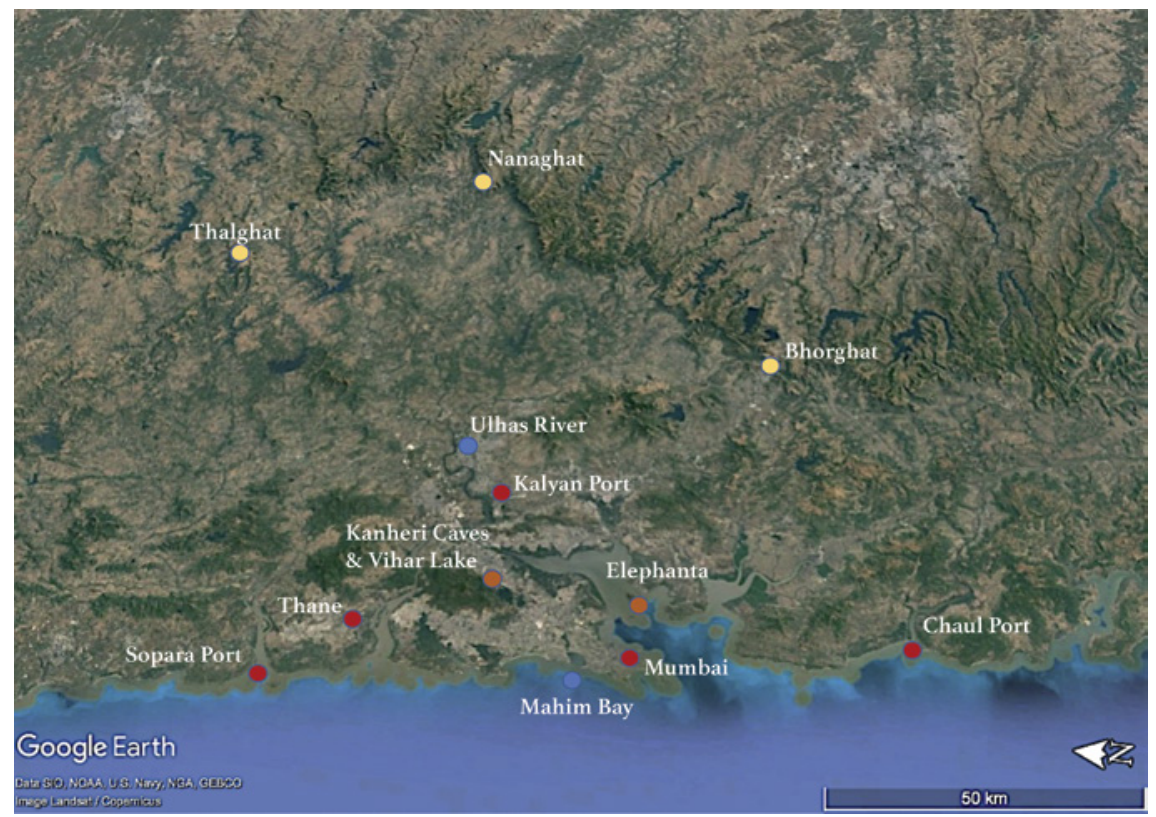

FIGURE $66 \quad$ North Konkan ports, cave sites, and mt. passes GOOGLE EARTH

overland routes, and through intercostal trade with the famous port of Broach in southern Gujarat (Lāta), the North Konkan was integrated within pan-Indian itineraries. ${ }^{23}$ To reach the coastal area of Lăța from the Deccan via overland routes, travellers would have faced formidable natural boundaries, most significantly the Narmadā River, which limited travel to particular routes. The primary point of crossing was at Māhișmatī (also called Māheśvar), ${ }^{24}$ a significant landmark in the geography of premodern India. This important crossing

sources also refer to the mining of gemstones and gold in the Deccan. As reported in the Periplus Maris Erythraei, mineral wealth and cloth produced from Deccan cotton eventually made its way to coastal Gujarat and Broach. Lionel Casson, Periplus Maris Erythraei: Text with Introduction, Translation, and Commentary (Princeton: Princeton University Press 1989), 83; Das, Deccan, 91-171; D. Schlinghoff, "Cotton Manufacture in Ancient India," Journal of the Economic and Social History of the Orient 17.1 (1974): 81-90.

23 In addition to the major passes, other small passes or trails were also utilized for trade and transport between the Konkan and the Deccan. Some of these are mentioned in the Gazetteer of the Bombay Presidency, Kolaba District, 114-116; Nasik District 125-137. See also D. Chakrabarti, The Archaeology of the Deccan Routes: The ancient routes from the Ganga plain to the Deccan (Delhi: Munshiram Manoharlal, 2005), 114-118.

24 H.D. Sankalia, B. Subbarao, S.B. Deo, The Excavations at Maheshwar and Navdatoli, 195253 (Deccan College, Pune \& M.S. University, Baroda, 1958); O.P. Misra \& R.K. Sharma, 
point facilitated travel between the agricultural and commercial centers of the Deccan and the cities of Ujjain and Mathura, nodal points along the major northern routes. ${ }^{25}$

\subsection{Regional Economy and Religious Landscape}

The dense clustering of both Buddhist and Śaiva caves sites along the North Konkan coast is compelling evidence that the area, with its many busy ports, provided a sufficient economic surplus to fund the construction of elaborate religious and residential centers and provide support to the populations of religious specialists that inhabited them, either permanent or seasonal residents [Figure 66]. ${ }^{26}$ The historiography on the early historic period $(500 \mathrm{BCE}-500 \mathrm{CE})^{27}$ of this region, by H.P. Ray and others, has emphasized the patterned embedding of Buddhist religious centers and monastic establishments at the heads of mountain passes and at crossroads along caravan routes. ${ }^{28} \mathrm{~A}$ pattern that is interpreted as evidence of the close association, even interdependence, of monastic communities and trade economy. Inscriptions from the Buddhist caves at Kanheri recording donations from merchants and guilds, some of them from places a great distance from the religious center itself,

Archaeological Excavations in Central India: Madhya Pradesh and Chhattisgarh (New Delhi: Mittal Pub., 2003).

25 For studies of these routes see M. Chandra, Trade and Trade Routes in Ancient India (New Delhi: Abhinav Pub, 1977); N. Lahiri, The Archaeology of Indian Trade Routes up to c. 200 BC: Resource Use, Resource Access and Lines of Communication (Delhi: Oxford University, 1992); D.K. Chakrabarti, Archaeology of the Deccan Routes; Jean Deloche, La circulation en Inde avant la révolution des transports, Tome I: La voie de terre (Paris: Publications de L'École Française d'Extrême Orient, CXXII, 1980).

26 At both the Buddhist and Śaiva sites there is evidence of settlements nearby. All of the North Konkan cave sites, Buddhist and Śaiva, have extensive facilities (e.g. tanks, cisterns, and wells) for the collection and storage of water, they likely served an important practical function as well. Water storage was critically important in the Konkan and the lack of fresh water outside of the monsoon period (June-September) has been the primary factor barring extensive industry and agriculture in the region. H.P. Ray, Monastery and Guild: Commerce under the Sātavāhanas (New Delhi: Oxford University Press, 1986), 17.

27 Special attention is paid to the period between the 1st and the 4th centuries CE as it was during this time that the excavation of Buddhist caves flourished and trade between India, Rome, and Egypt also flourished under the Sātavāhana rulers who had established their capital at Paithan.

28 Ray, Monastery and Guild, 87; James Heitzman, Gifts of Power: Lordship in an Early Indian State (Delhi: Oxford University Press, 1984), 131; Jason Neelis, Early Buddhist Transmission and Trade Networks: Mobility and Exchange Within and Beyond the Northwestern Borderlands of South Asia (Leiden: Brill, 2011), 215-217. 


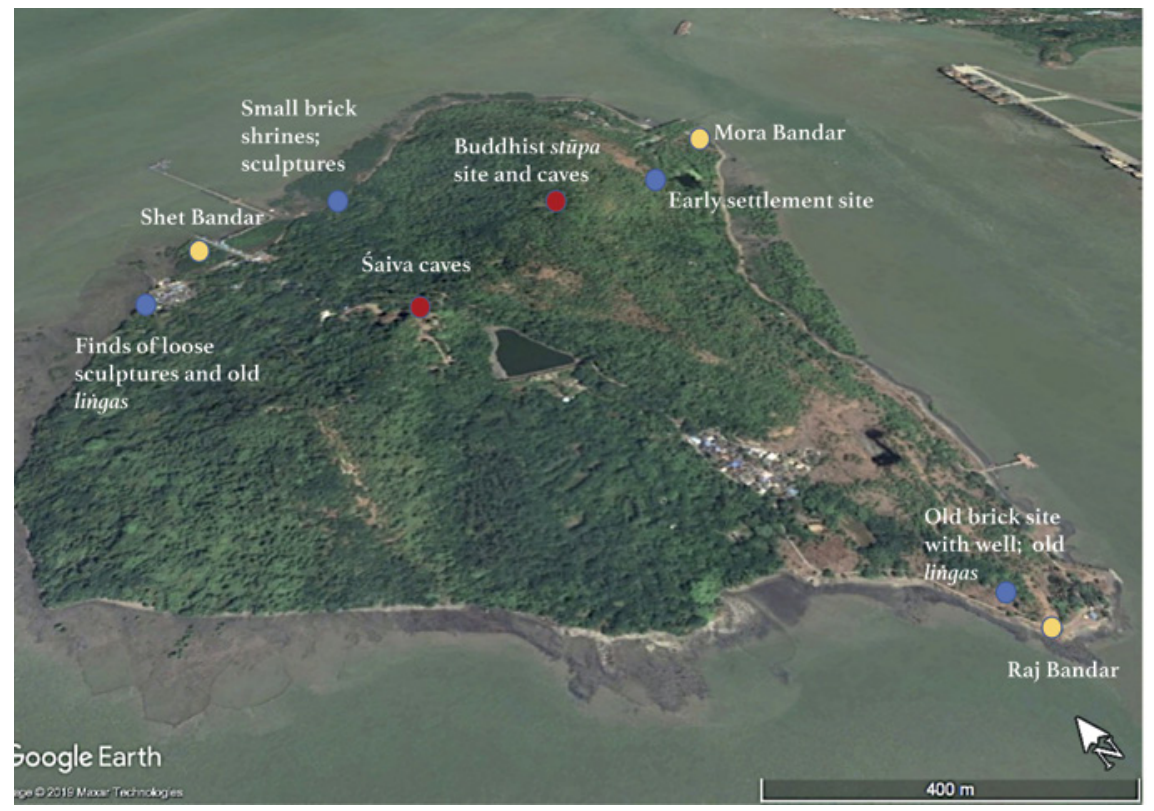

FIGURE 67 Elephanta Island

GOOGLE EARTH

further support the interconnectedness of Buddhism and trade in this area. ${ }^{29}$ The spatial logic of the Śaiva religious landscape gestures to the Buddhist model — both were designed to capitalize on the economic surplus generated by the coastal economy.

Buddhist and Śaiva religious centers developed in close proximity to one another and some Buddhist centers, such as Kanheri, remained active in the 6th and 7 th centuries when the Saiva caves were also in use. The multilayered character of the religious landscape is most clearly evident on Elephanta Island [Figure 67]. The Śaiva excavations at Elephanta represent only the best preserved of several religious sites on the island. An earlier

29 A number of inscriptions from the Buddhist caves at Kanheri mention donors from the surrounding port cities of Chaul, Kalyan, and Sopara, as well as Nasik and range in dates from the ist through the 6th centuries CE. H. Lüders, "A List of Brāhmī Inscriptions from the earliest times to about AD 400. With the exception of those of Aśoka," EI 10 (1909), Appendix A, 1-226 (nos. 100, 996, 988, 985); "Kanheri Plate of the Traikūṭakas: K.S. 245 (493/4 or 494/5 CE)," CII 4, 29-32. In particular, note the inscription from Kanheri Cave 3 that records the collaborative donative efforts of merchants and monastics in the excavation of a caitya. G. Bühler, "Kānheri Inscriptions," ASWI 5, 74-87 (no. 4); Lüder's List, no. 987 . 


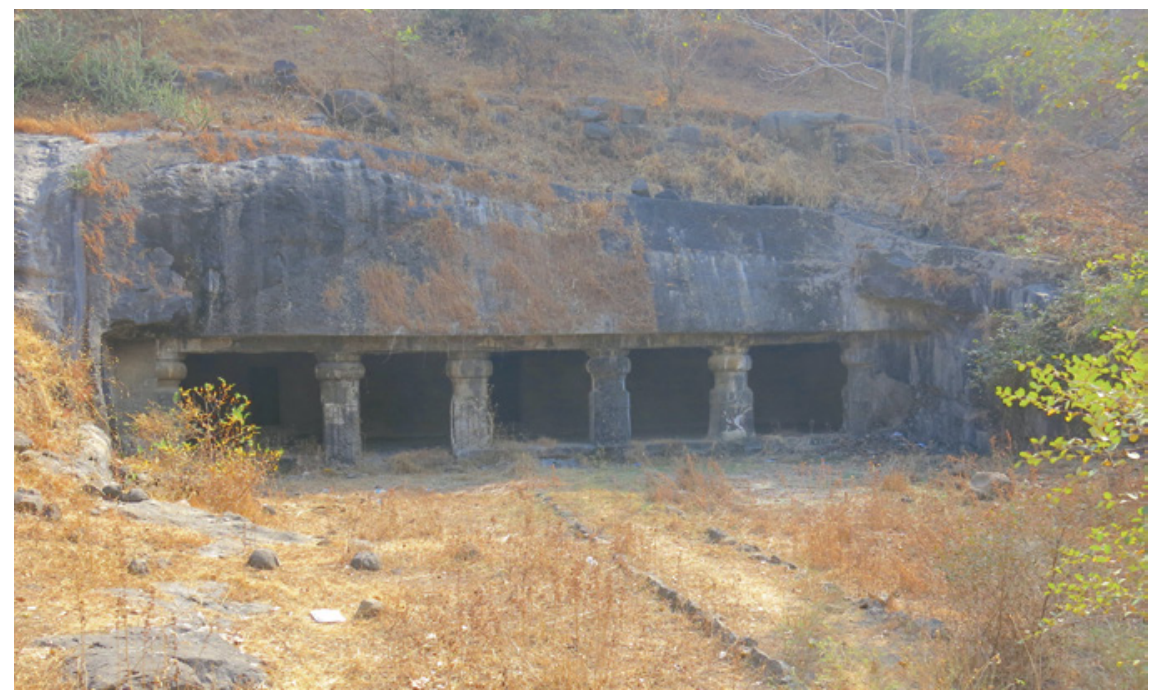

FIGURE 68 Excavated caves near stūpa site, Elephanta Island

Buddhist site dominated the hill directly opposite the Śaiva caves in the vicinity of Mora Bandar, the oldest of the island's three jetties, where the remains of a Buddhist stüpa and an early settlement site were excavated [Figures 68]. A series of simply excavated caves occupied this same hill, along with tanks for collecting water. It is difficult to ascertain whether these caves were originally affiliated with the Buddhist community or the Śaiva community. At the time of the Portuguese explorer De Couto's report one cave contained an active linga shrine and two multi-armed goddesses occupied another. The reports of De Couto, Burgess and Cousens, and other 19th century reports summarized in the Bombay Gazetteers mention the remains of small brick shrines along the island's coast where a number of lingas and other loose sculptures were found. These include the images of Brahmā, Viṣnu, Śiva, and Mahișāsuramardinī recovered from the island and now held in the Chhatrapati Shivaji Maharaj Vastu Sangrahalaya in Mumbai ${ }^{30}$ [Figures 69-71].

Like the Elephanta caves, the Śaiva caves of Jogeśvarī and Maṇapeśvar were also constructed in close proximity to Buddhist institutions and strategically placed in economically advantageous areas near ports and navigable coastal rivers. Śaiva communities may have even co-opted earlier Buddhist excavations. For example, K.V. Soundara Rajan suggests that the southernmost cave at Mandapeśvar was originally a simple Buddhist excavation that was further excavated and expanded by communities of Śiva devotees. Unlike Elephanta

3o Gazetteer of the Bombay Presidency, Thana District Revised ed. 1982 (first ed. 1882). 


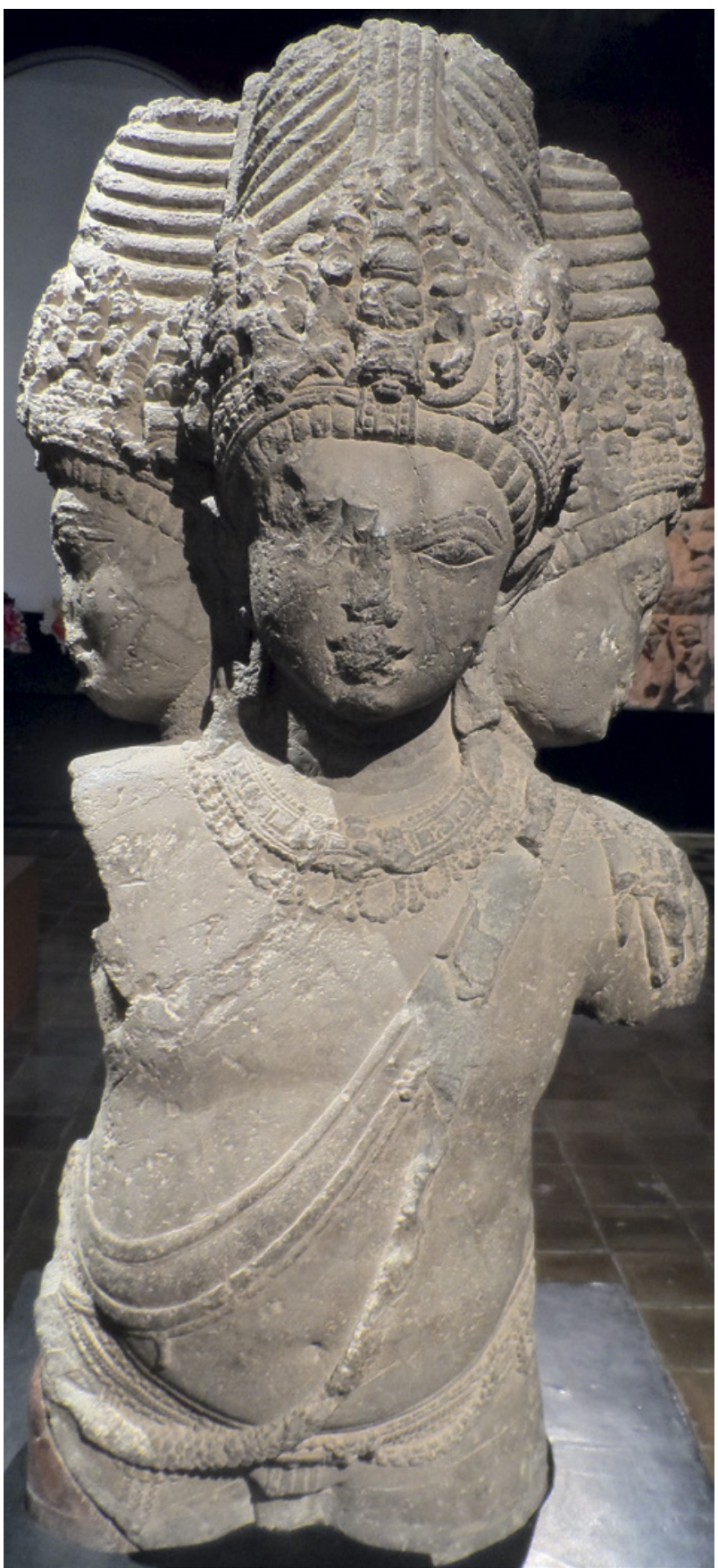

FIGURE 69 Sculpture of Brahmā from Elephanta Island,

c. 7 th century

CSMVS MUMBAI 


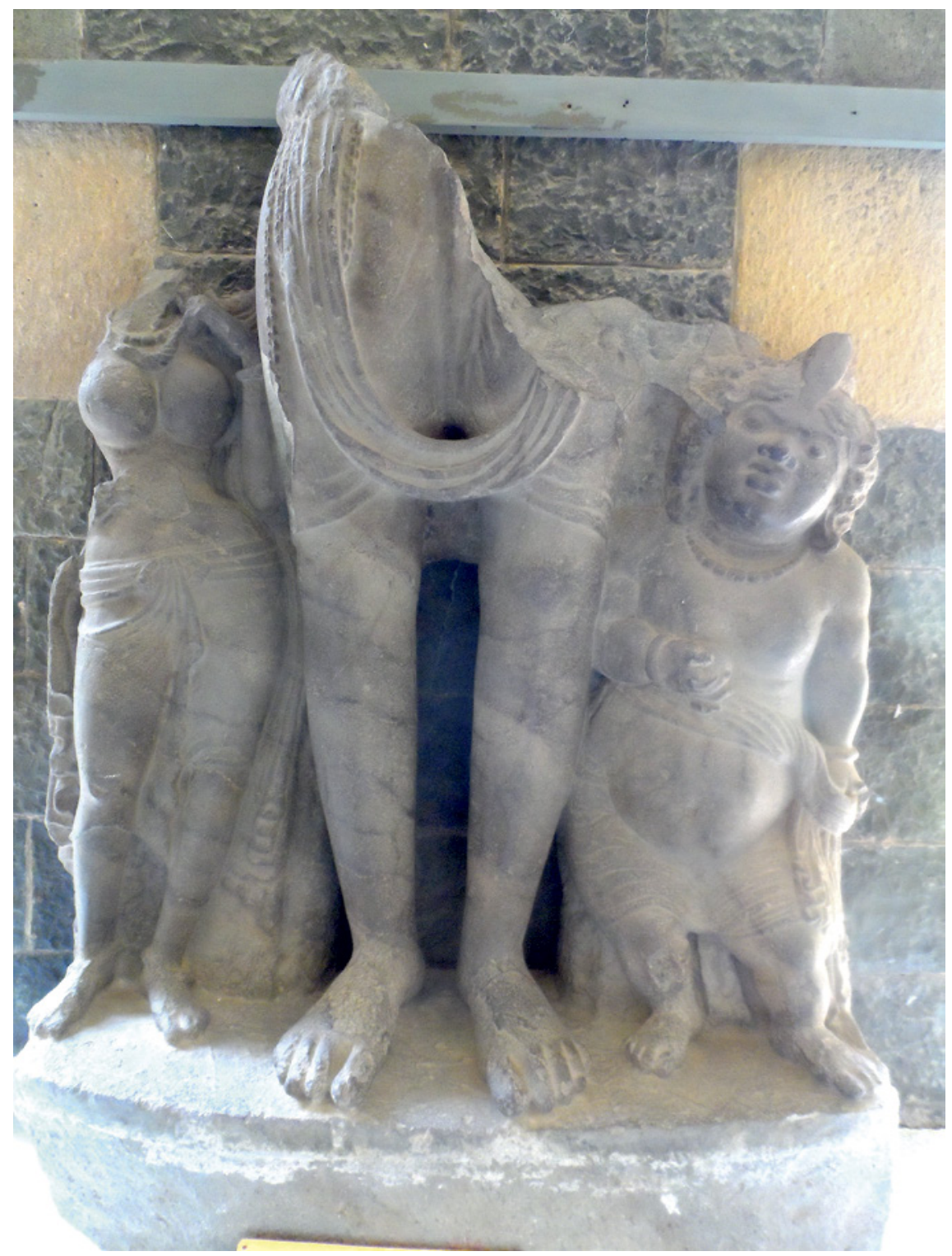

FIGURE 70 Sculpture of Viṣnu (lower portion) from Elephanta Island, c. 7 th century CSMVS MUMBAI 


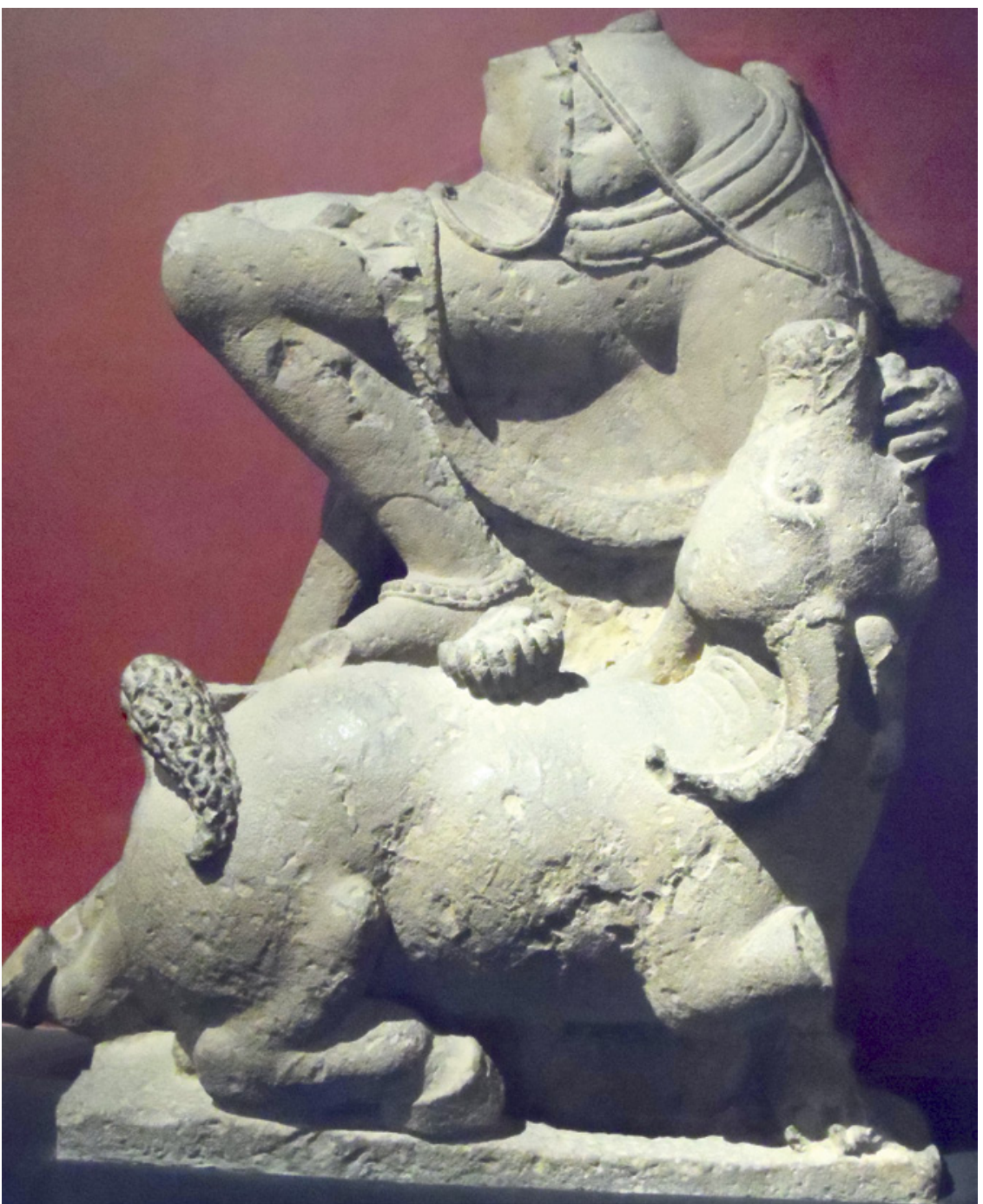

FIGURE 71 Sculpture of Mahișāsuramardinī from Elephanta Island, c. 7 th century CSMVS MUMBAI

and Jogeśvarī, it does not seem that the main temple sanctum originally held a linga. ${ }^{31}$ Given that workable sites for constructing monuments were limited by

31 Rajan reports, "Within the door-frame is a square chamber [...] without any apparent indication of a provision for linga pițha or linga of the monolithic type on its floor [...] Although there is a pestle like stone kept in its center inside the depression, it has no relationship either with the pit as cut original or with the pristine character of the chamber itself." Rajan, Cave Temples of the Deccan, 94-98. 
various conditions of the physical geography, it would make sense that members of the Śaiva community would repurpose a locale used by earlier patrons. ${ }^{32}$

While economic realities have been emphasized in studies of Buddhism, studies of brahmanical religions in the early medieval period remain influenced by the historiography of what is commonly termed medieval 'feudalism' and the assumption that trade and commercial networks declined following the end of the Gupta-Vākātaka period. This perceived decline in market economies is thought to have made the village an autonomous and non-monetized economic center. ${ }^{33}$ In this view, villages were "individually self-sustaining units, devoid of channels connecting them with other kinds of production or with centers of commodity exchange." ${ }^{34}$ Recent work of archeologists and historians shows that the theory regarding the dearth of trade in the early medieval period is inaccurate. ${ }^{35} \mathrm{In}$ fact, long-distance trade continued to flourish along new and dynamic trajectories. ${ }^{36}$ Studies of ceramics provide corroborating evidence for these patterns of exchange as early as the 6th and 7 th centuries. Roberta Tomber's work on the distribution of amphorae in India demonstrates that while the circulation of Early Roman amphorae was concentrated in the 1st century BCE to 2nd century CE around the port of Chaul, and the nodal trade centers of Nasik and Paithan in the Deccan, later styles of amphoraesuch as Red Sea amphorae and Torpedo jars produced in modern Aqaba in

32 On the workability of stone and processes of creating rock-cut sites see Vidya Dehejia and Peter Rockwell, The Unfinished: Stone Carvers at Work on the Indian Subcontinent (New Delhi: Roli Books, 2016), 14-27.

33 B.D. Chattopadhyaya, "State and Economy in North India," in Recent Perspectives of Early Indian History, ed. Romila Thapar (Delhi: Popular Prakashan, 1995), 322-23.

34 Chattopadhyaya summarizing (rather polemically) the position of D.D. Kosambi, An Introduction to the Study of Indian History (Bombay: Popular Book Depot, 1956), R.S. Sharma, Indian Feudalism, c. 300-1200 (Calcutta: Univ. of Calcutta, 1965), and others. See also Anjali Malik, Merchants and Merchandise in Northern India AD 6oo-10oo (Delhi: Manohar Publishers, 1998), 93.

35 For example, see H.P. Ray, "The Artisan and the Merchant in Early Gujarat, Sixth-Eleventh Centuries," Ars Orientalis 34 (2004): 39-61. Ray stresses the autonomy of merchants and artisans in relation to state and political power. Also, André Wink, Al-Hind: The Making of an Indo-Islamic World (New Delhi: Oxford, 1990), 45-64. Wink rejects even the hypothesis that Roman trade declined during this period and cites the continued activity of Greek and Byzantine traders in Indian Ocean commerce.

36 Overseas trade with the Roman Empire and the Mediterranean declined, yet studies of Arab and Persian sources show that international trade continued and that new networks were established, particularly from the 8th and early 9th century. Patterns in early medieval trade in the North Konkan are addressed in a series of articles by Ranabir Chakravarti, starting with "Merchants of Konkan," The Indian \& Economic Social History Review 23.2 (1986): 207-215. On broader Indian Ocean patterns see K.N. Chaudari, Trade and Civilisation in the Indian Ocean: An Economic History from the Rise of Islam to 1750 (Cambridge University Press, Cambridge, 1985), 15. 
Jordan from the $4^{\text {th }}$ through the $7^{\text {th }}$ century - are found almost exclusively at Elephanta and the ports of southwest Gujarat. ${ }^{37}$ The presence of these unique pottery styles attests to the continued dynamism of exchange networks along the North Konkan coast in the 6th and 7 th centuries, in which places like Elephanta played a central role.

\section{$2 \quad$ Politics and Patronage}

Control over the North Konkan and northwest Deccan offered a considerable economic advantage for the many lineage groups aspiring to political power in the centuries following the decline of Gupta-Vākātaka sovereignty As a borderland between more stable polities to the north and the south, this area was a repeated site of contestation in which political boundaries were routinely redrawn as a result of military incursions and raids, and political hierarchies ever shifting as political alliances were dissolved and reconfigured. ${ }^{38}$ Inscriptions from multiple ruling families between the 6th-9th centuriesincluding the Traikūṭakas, Mauryas, Sendrakas, Kalacuris, Cālukyas, Gurjaras and Rāștrakūtas, among others-record competing claims of sovereignty. The distribution of epigraphic records indicates that the influence of the region's ruling elites was narrowly constrained, and political competition was most fierce around the nodal points along the regional trajectories at the heart of the northwest Indian economy (i.e. in Lăța around Broach, Ujjain, and the Nasik District of the northwest Deccan). In addition to these ruling dynasties, inscriptions also record the activities of various generals, local elites, merchant collectives and guilds who emerge as important players in the political arena, often operating with a great deal of autonomy. ${ }^{39}$ It is striking, however, that royal inscriptions are not found in significant number in the North Konkan itself. I interpret this epigraphic pattern as evidence that the coastal area was a distinct, and relatively autonomous, commercial zone. ${ }^{40}$

37 See Roberta Tomber, "Beyond Western India: The Evidence from Imported Amphorae," in Indian Ocean Commerce and the Archaeology of Western India, ed. R. Tomber, L. Blue, and S. Abraham (London: British Association for South Asian Studies, 2010), 42-57.

38 On the larger political context of this historical period see H.T. Bakker, The World of the Skandapurāna, especially "Part 1: The World of Power," 25-133.

39 Romila Thapar, A History of India Vol. 1 (London: Penguin, 1966), 110-112; K.K. Thaplyal, Guilds in Ancient India: A Study of Guild Organization in Northern India and the Western Deccan from 600 BC to $600 A D$ (New Delhi: New Age International), Chapter 7 "Guild and the State," 121-139.

40 This hypothesis is developed further in a separate article. Elizabeth A. Cecil, "Power and Piety in 'Emplaced Polities': Temple Patronage and Donative Practice under the North 
After a brief survey of the political terrain, this section explores the religious landscape and considers what role regional political elites may have played in the construction of Śaiva sites. Although the Kalacuris, and other ruling elites, proclaim devotion to Śiva in their records, a closer look reveals these professions of religious identity are less straightforward than has been assumed, and in their acts of patronage rulers tended to favor gifts to brahmins over temples. To understand the patterns in religious giving that could have contributed to the creation of the monumental Śaiva cave temples, I focus on the networks of merchants and local collectives also active in these regions. The sources indicate that these communities were more invested in religious life 'on the ground' than were rulers at the time. Examining these alternative networks of patronage will afford us a new perspective on the development of the North Konkan's built religious landscape.

\subsection{The Political Landscape}

In the late $5^{\text {th }}$ and early 6 th century, inscriptions of the Traikutataka rulers found in southern Gujarat, around Nasik, and in the South Konkan record some of their activities in the greater Konkan region. Four sets of Traikuttaka copper plates are known. Three were issued by the rulers themselves, and the fourth, a set of copper plates from the Kanheri caves in Mumbai, locates itself in the period of their rule. ${ }^{41}$ These kings claimed a city called Aniruddhapura ('The Unassailable City') as their capital, but the location of this city is uncertain. Previous scholars have proposed a location on the west coast, perhaps Surat in southern Gujarat. ${ }^{42}$ While Surat cannot be dismissed as a possibility, my study of the regional political geography supports a new, and more plausible hypothesis. The Traikūtakas positioned their political center around Nasik

Konkan Śilāhāras (9th-12th CE)," in Puṣpikā: Tracing Ancient Indian Through Texts and Traditions, eds. Lucas den Boer \& Daniele Cuneo (Oxford: Oxbow Books, 2017), 213-231.

41 These include the Surat Plates of Vyāghrasena KS 241 (490 CE) and the Pārḍi Plates of KS 207 ( $457 \mathrm{CE}$ ), found 50 miles south of Surat. The first was issued from their capital at Aniruddhapura, and the second from a victorious military camp, Āmrakā, presumably in the Surat District. Both record the donation of land to brahmins. Two additional grants were found south of Mumbai in Mațan (Ratnagiri District of Maharasthtra), the first issued by Madhyamasena in 256 A.S. ( $505 \mathrm{CE}$ ) and the second by Vikramasena in 284 A.S. (533 CE). CII 4, 22-32, and Plates.

42 Mirashi suggests a location in the Surat district for Aniruddhapura since two of the Traikūțaka grants were issued from villages near Surat, but these locations are referred to as military camps rather than permanent settlements. Mirashi, $C I I 4$, xliv; 27-28. The name of the city could be a reference to its being somehow unconquerable (aniruddha). The name aniruddha could also refer to one of the Vṛṣnis as a way to signal the Vaiṣnava affiliations of the rulers. 
and the Thalghat, and near the 'three-peaked mountain' (trikūța) that served as their dynastic namesake. Epigraphic and literary sources use the designation 'Trikutta' to refer to the range of the Sahyādris on the western border of the Nasik District and the administrative entity located there. ${ }^{43}$ The Nasik area was a central locale from which these rulers could expand their power-base in the northeast, around Surat, where they had established military camps, and southeast, toward the Ratnagiri distinct of the South Konkan, where their copper plates were also found. As far as their religious identity and donative practices are concerned, the Traikuttakas identified themselves as devotees of Viṣnu (i.e. Bhăgavatas) in their coins and inscriptions. In both the Surat and Pārḍī Plates, for example, the rulers Vyāghrasena and Dahrasena are eulogized with the epithet bhagavatpädakarmakara (servant at the feet of the Bhagavat, i.e. Vișnu).

The Traikūtakas faced considerable competition for control over their namesake region from political rivals to the south, east, and north. For example, Viṣnukuṇ̣̣in Mādhavavarman III claimed to have been the lord of Trikūṭa in the mid-5th century. ${ }^{44}$ A similar claim was made by the Vākāțaka Harișeṇa in an inscription from Ajanta Cave XVI in the late 5 th century. ${ }^{45}$ Inscriptions of the Mauryas found in the South Konkan attest to the political ambitions of these regional rulers. ${ }^{46}$ And to the north, around Broach, a ruler named Sangamasimha issued a grant in KS $292(541 \mathrm{CE})$ donating land in the 'antar narmadā vișaya' (the administrative zone through which the Narmadā River flows) to brahmins from Broach. ${ }^{47}$ Since this area would have included land

43 Mirashi and Rajgor follow Kalidāsa (Raghuvaṃśa 4.58-59) in identifying trikūṭa with the Sahyādri, i.e. the Sahya Mountain. The reference to the pürvatrikūțavișaya in the eighth century Anjaneri Plates (Nasik District) supports this identification. The Nasik Cave 10 inscription refers to the mountain there as triraśmi (three-rayed), which could allude to the three peaks (Mirashi, CII $_{4}$, xli).

44 Though the Viṣnukuṇ̣in central locus of power was in Andhra, their power may have extended into the southwestern Deccan as suggested by an inscription found in Khanapur in the Satara District of Maharashtra. V.V. Mirashi \& Y.R. Gupte, "Khanapur Plates of Madhavavarman," EI 27 (1947): 312-318.

45 Bakker, Vākātakas, 1997, 34-35; Sircar, Select Inscriptions I, 453 (vs. 18).

46 G.S. Gai, "Bandora Plates of Maurya Anirjitavarman, Year 29," EI 33 (1960): 293-297; D.C. Sircar, "A Note on the Goa Copper Plate Inscription of King Candravarman," Annals of the Bhandarkar Oriental Research Institute (1942): 510-514.

47 Sangamasiṃha calls himself a mahāsāmanta, suggesting he was a political subordinate to a larger power, but this superior is unnamed making it difficult to situate Sangamasimpha within the broader political landscape. Sangamasimha may have been a subordinate of the Kalacuris since the area around Broach was claimed by the Kalacuri Śankaragana in the late 6th century. CII 4, "Sunao Kala Plates of Sangamasiṃha: K.S. 292" (541 CE), 
on both sides of the Narmadā River, it would have bordered the Traikūtakacontrolled region quite closely.

In addition to the political rivals mentioned above, a reference in the Matvan Plates of the Traikūțaka king Vikramasena (KS 284) 533 CE introduces yet another claim to Traikuttaka territory by the Kalacuri rulers. These plates, along with an earlier set found at the same location, allude to a transition or struggle for power between the Kalacuris and the Traikūṭakas. The first set of Matvan Plates was issued from Aniruddhapura in $506 \mathrm{CE}$, which is described as the "victorious city of the Traikūṭakas" (vijayāniruddhapurāt traikuttakānām). In the second set of Matvan Plates, issued in $533 \mathrm{CE}$, the name of the Traikutakas was replaced with the Kalacuris [variant spelling] (vijayāniruddhapurāt kațaccurīnām). The Traikūțaka king, Vikramasena, is still identified as the ruling sovereign, but Aniruddhapura is called the 'victorious city of the Kalacuris'. ${ }^{8}$ Based upon this change, Mirashi and Gokhale suppose that the Traikūtakas became political subordinates of the Kalacuris in the 6th century. It is difficult to gauge the political situation from this single reference, a difficulty compounded by the fact that the exact location of the city is contested. Following my hypothesis that Aniruddhapura was located near Nasik, then the Kalacuri claim to this area fits within the general geographic distribution of their inscriptions, as shown below.

While it is uncertain if the Kalacuris ever had a capital city to speak of, the historiography of the period associates them closely with the town of Māhișmatī on the Narmadā River. ${ }^{49}$ This connection is plausible since the sphere of Kalacuri political influence was northwest and central India, specifically around Ujjain, Vidiśā, and sites in south-central Gujarat where they had established military camps [Figure 72]. To control sites both north and south of the Narmadā would have necessitated some control of Māhiṣmatī since this prominent tirtha was one of the few places where the Narmadā could be

33-37. On the 'antar narmadā vișaya' see J.F. Fleet, "Note on Indian History and Geography," IA 32 (1903): 40-57 (56).

48 Mirashi, CII 4, clxvii; "The Riddle of the Māțvan Plates of the Traikūṭaka King Vikramasena: Ābhira year 284," in Literary and Historical Studies in Indology (Delhi: Motilal Banarsidass, 1975), 125-130; Shobhana Gokhale, "Matvan Plates of the Traikutaka king Vikramasena: K.S. 284," in Studies in Indology and Medieval History: Professor G.H. Khare Felicitation Volume, Mate and Kulkarni eds. (Poona: Joshi \& Lokande Prakashan, 1974), 86-94.

49 In the relatively short temporal span represented in the records, the Kalacuris were operating from military camps in northwest and central India and these rulers had no fixed capital city to speak of. The connection of the early Kalacuris with the town of Māhișmatī on the Narmadā is likely anachronistic as it is based on the reading of later Kalacuri (i.e. Haihaya) records in which the rulers claim descent from Arjuna Kārtavīrya, legendary king of Māhișmatī. See Mirashi, $C I I$ 4, xliv. 


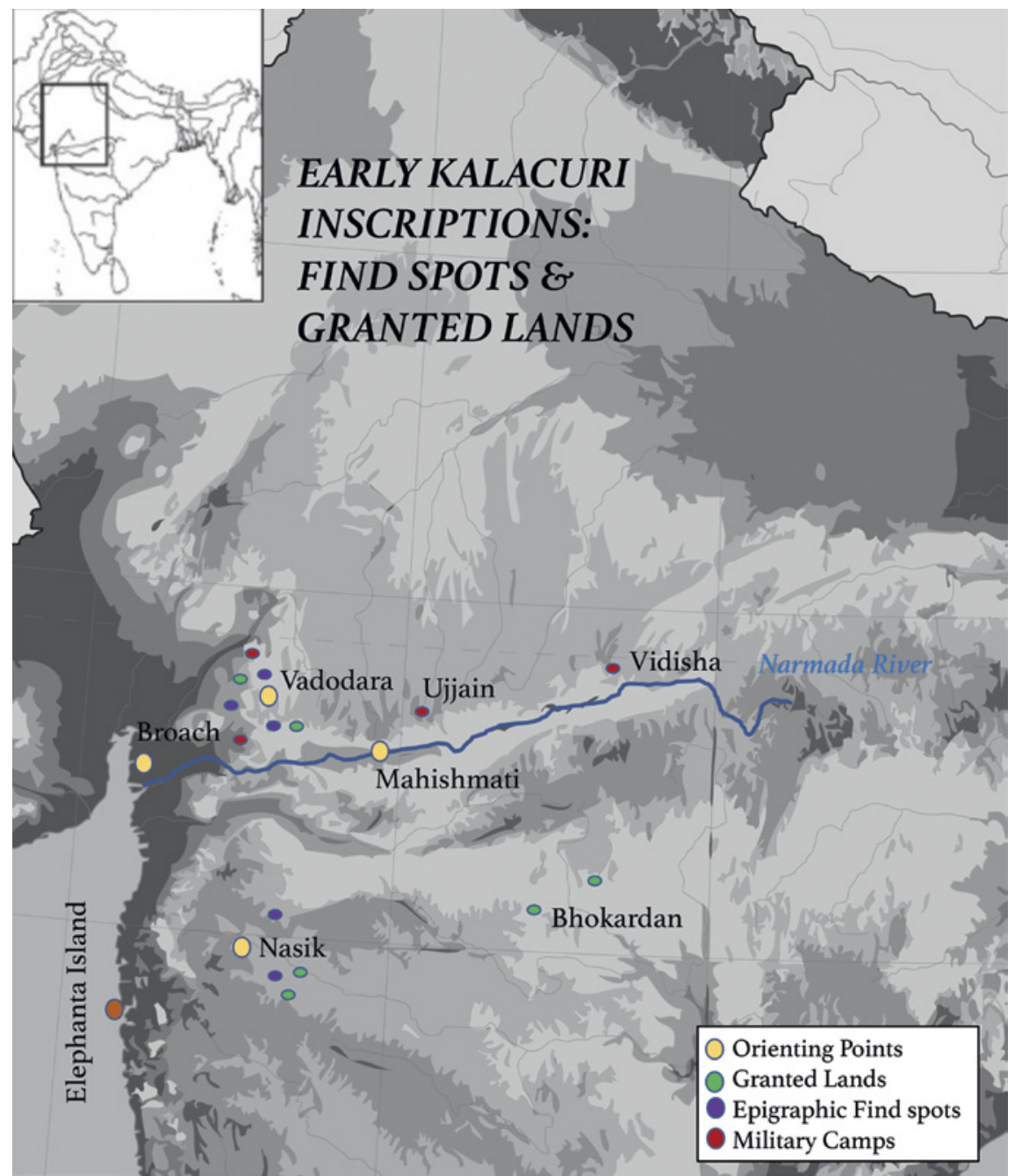

FIGURE 72 Map of Kalacuri epigraphic find spots and granted lands

crossed. Some of the lands granted in the inscriptions were located in what is now the Nasik District of Maharashtra, an indication that their political influence extended to the western Deccan as well. The villages granted in the Nasik District were a considerable distance away from their military encampments, but would have afforded access to the Thalghat, one of the three major passes through the Western Ghats. The Kalacuris were not unique in adopting this strategy of economic control. Control over the Deccan routes was integral to the success and expansion of Sātavāhana polity and inscriptions of Kalacuri contemporaries were also found near the same nodal points. 
There are five known early Kalacuri inscriptions. The earliest of these were issued by Śankaragana, who is thought to have ruled from approximately 575-60o CE. ${ }^{50}$ In his records he praises his father Kụṇaraāja, the first known Kalacuri king. No records issued by Kṛ̣narāja have survived, but copper coins bearing the legend 'Śrī Kṛ̣narāaja' with a couchant bull on the reverse have been found in the Deccan and the North Konkan. ${ }^{51}$ His silver coins, dispersed even more widely, were found in Rajasthan, the North Konkan, and in Vidarbha. Śankkaragana's son, Buddharāja issued two grants in the early 7 th century, one from a military camp at Vidiśā, and the other from a military camp at Ānandapura (modern Vaḍnagar, approximately $100 \mathrm{~km}$ north of Ahmedabad in northern Gujarat).52 Following the defeat of Buddharāja in the early

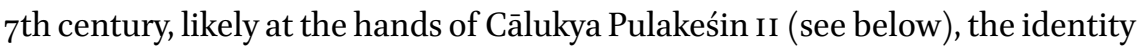
of his successors and their activities is difficult to trace with certainty. ${ }^{53}$

50 Śankkaragana's inscriptions include the Lapkaman grants K.S. 345,347 (595 CE, Ahmedabad District), which record the donation of lands in south-central Gujarat. These were followed by the Abhona grant K.S. 347 (596-97 CE) issued from a military camp at Ujjain and found at Abhona in the Nasik District and record the donation of lands in Bhogavardhana (Bhokardhan), the specific village named is Vallisika (Valsa) 7 miles south of Bhokardhan in Aurangabad District. The Sankheda grants (Baroda District, northwest of Broach) were issued from a military camp at Nirgundịipadraka, in southeast Gujarat, by Śankaragana's general Śantilla. This record is undated, but is thought to be from the late 6th century based upon the dates of Śankaragana's other inscriptions.

51 CII 4, xlvi; R.K. Sharma, Coinage of Central India: Early Coins from the Narmada Valley (New Dehi: Aryan Books International, 2011), 5; 33-34; On the silver coins see J.F. Fleet, "On the Silver Coins of the Early Guptas and others connected with them," IA XIV (1885): $65^{-68}$ (68).

52 His Vāḍner Plates K.S. 360 (610 CE, Nasik District) issued from a military camp at Vidiśā and his Sarsavni Plates K.S. 361 (610 CE, Vadodara District) issued from a military camp at Ānandapura (modern Vaḍnagar in northern Gujarat). CII 4, 47-56. The Kalacuris may have cultivated alliances in southern Gujarat. A grant dated (KS 346) 595-6 CE mentions an individual named Taralasvāmin who is described as the light in the house of the Kalacuri family' (kataccurikulaveśmapradipa). Mirashi deems the grant spurious, since Taralasvāmin does not mention his political superior who, judging from the Abhona grant issued in the following year, would have been Kalacuri Śankaragana. But it may be that Taralasvāmin was a member of a subordinate (or even a competing) family that was also attempting to lay claim to Broach. "Spurious Mānkaṇī Plates of Taralasvāmin: K.S. 346," CII 4, 160-165. R.C. Majumdar, The Classical Age, 2nd ed. (Bombay: Bharatiya Vidya Bhavan, 1960), 197.

53 It may be that they continued to rule under the control of the Cālukyas or they moved east toward Jabalpur (Tripuri) where later branches of the dynasty are attested from inscriptions in the mid-8th century. According to Mirashi, the next known actor from the Kalacuri camp is Vāmarāja $\left(675^{-700 ~ C E) ~ w h o, ~ a f t e r ~ t h e ~ d e a t h ~ o f ~ H a r s ̦ a ~ i n ~ t h e ~ l a t t e r ~ h a l f ~ o f ~}\right.$ 7th century, took control of Kālañjara fort, which had long been a site considered sacred to Śiva. See Bakker, The World of the Skandapurāna, 213. 
Given the key locales mentioned in their inscriptions it is evident that the Kalacuri military and political strategy was aimed at controlling 'nodal' points along the major trade routes and, more specifically, those points at which regional, subsidiary routes joined with the major north-south trajectories (for example, Broach, Ujjain, and Vidiśā). Kalacuri control over these places also accounts for the widespread distribution of Kṛṣnarāja's coins, including those found on Elephanta Island. The presence of Kalacuri copper coins on the island is commonly cited as proof of Kalacuri patronage of the cave temples. Shobana Gokhale and Spink offer the unconvincing hypothesis that these coins were paid to the laborers working in the caves. ${ }^{54}$ These coins are, in fact, not unique to Elephanta. Kṛșnarāja's copper coins were found elsewhere in the Deccan, and his silver coins have been found throughout northwest and central India where they could have been circulated via commerce between the Konkan ports and the Kalacuri-controlled hinterlands. ${ }^{55}$ As a final point, since Kṛșnarāja's coins were still in use in the Deccan 150 years after the period of his rule-as evinced by the mention of taxes paid in 'krșnäräja-rüpakas' in an early 8th century inscription - we need not assume the distribution of the coins indicates the geographic extent of Kṛ̣naraāja's territory. ${ }^{56}$

\subsection{What's in a Name: the Politics of Religious Identity}

Considering the dynamism of the political landscape around the Sahya Mountain, it is unlikely that the construction of the Śaiva monuments was the work of one particular ruling family. Although the Kalacuri rulers identified themselves as devotees of Śiva-an affiliation expressed consistently through epithets given in their inscriptions - their donative records contain

54 One of Kṛṣnarāja's silver coins was found in the courtyard of the Rāmeśvara cave temple at Ellora and this find has been cited by Spink as evidence for Kalacuri patronage there. Shobhana Gokhale, "Elephanta Hoard of Copper Coins of Kṛṣnarāja," Journal of the Numismatic Society of India 38.2 (1976): 89-91; Mirashi, cII 4, xlvi.

55 Nor are finds of copper coins unique to Elephanta as Spink has claimed Spink, "Elephanta," 236. Since Spink reports that many, if not most, of the copper coins found at Elephanta are extremely corroded, it is possible that they are not all Kalacuri issues. Burgess and Indraji reported the discovery of more than one thousand copper coins at Lake Vihar near the Kanheri caves on Salsette Island in the mid-19th century, some of which are comparable in size to the Kalacuri copper coins. According to Burgess's report, "During the excavations in making a path round the upper contour of the great reservoir at Vihar in Salsette, in January 1855, upwards of a thousand copper coins were dug up in an earthenware pot ... Many are corroded, half a dozen are distinctly Muhammadan, others have some variation of a cross symbol with four cardinal points marks." Dimensions reported by Gokhale: round diam: $1.02 \mathrm{~cm}$ to $1.5 \mathrm{~cm}$. See Burgess and Indraji, Inscriptions of the Cave Temples of Western India (Bombay: Government and Central Press, 1881 [1976]), 66. 
no mention of temples or religious monuments. To resolve this apparent disconnect between royal epithets and the reality of donative practices requires that we reconsider the politics of religious identity in this historical period.

Religious identity was clearly an important facet of the Kalacuri political persona. Śankaragana, for example, describes himself as a paramamāheśvara, "completely devoted to the Maheśvara, (namely, Siva)" and declares that his father, Kṛ̣naraāja, was devoted to Paśupati (paśupatisamāśraya) from birth. ${ }^{57}$ No inscriptions issued by Kṛ̣nararāja have survived, but his coins bear the legend paramamāheśvara and the image of a bull on the obverse has been interpreted as representing Śiva's iconic vehicle. The family preference for Śaivism is affirmed by Śankkaragaṇa's son, Buddharāja who also identifies himself as a māheśvara and copies verbatim the Pāśupata affiliation from his father's inscriptions. Buddharāja's wife, Anantamahayī, follows suit, calling herself pāsupatarajjñ̄. ${ }^{58}$ The names of many of the individuals involved in the issuing of their inscriptions further indicate the influence of Śiva devotion within their political circle. ${ }^{59}$ In light of this preference for Śaivism, the fact that none of the known Kalacuri inscriptions allude to the construction of religious monuments or temples is significant. If Kṛṣnarāja had sponsored a monument on a par with Elephanta, one would expect some mention of it in records of his successors, which praise him at length. ${ }^{60}$

The widespread use of the epithet paramamāheśvara among political elites indicates that it was becoming a political idiom. Contemporaneous epigraphic records show that the Kalacuris were in esteemed company in adopting this title. Members of competing and ruling families in northwest India-including the Maitrakas, Gurjaras, and Sendrakas-also adopted the moniker, ${ }^{61}$ but the majority of these records commemorate land-grants to

57 CII 4, "Ābhona Plates of Śańkaragana: K.S. 347," 38-43. In addition, the suffix -gana in the name Śankkaragana suggests a Śaiva affiliation. See Chapter 2 n. 84.

58 CII 4, "Vaḍner Plates of Buddharāja: K.S. 36o," 47-50.

59 The composer of the Sarsavni inscription was named Śivarāja. The dūtaka for the Lapkaman and Abhona Plates was named Pāśupata. On this topic see also Annette Schmiedchen, "Patronage of Śaivism and Other Religious Groups under the Dynasties of the Kataccuris, Gurjaras and Sendrakas from the 5 th to the 8th centuries," Indo-Iranian Journal 56 (2013): $349-363$.

6o In the Abhona Plates, Kṛṣnarāja is lauded primarily for his military prowess. Mention is made of his generosity and charitable donations made for the sake of gaining religious merit, but these statements are communicated in a general way and no specific donations or events are mentioned.

61 For example, some of the Maitraka rulers called themselves māheśvaras: In the Maila Plates of Dharasena II the king describes the lineage progenitor, Bhațaraka as a māheśvara (cII 3, no. 38. Plate XXIV). Guhasena adopted both the epithets paramopāsaka 
brahmins. ${ }^{62}$ Royal patronage of Śaiva institutions in this particular area did not flourish until the 1oth century under the Silāhāra rulers. ${ }^{63}$ In their donations, the Kalacuris chose, like their political contemporaries, to extend their patronage to brahmins through grants of land and villages to support the continuation of their ritual practices. Rather than endowing monuments, showing support for brahmins and acting as the patron of their sacrifices remained some of the defining aspects of the king's royal persona. By normalizing this popular royal epithet, my intention is not to exclude the possibility of Kalacuri donations to temples or religious institutions. Rather, I wish to question the prevailing assumptions that expressions of Śaiva religiosity necessarily entailed the 'monumental' context of a temple, and that every temple constructed during this period functioned as a 'royal center'. The construction of the Śaiva cave temples would have required a surplus of time and capital and such undertakings may not have aligned with the larger Kalacuri political strategy as they worked to maintain their control over the nodal centers of trade and exchange in central India and the Deccan.

\subsection{Building Temple \& Community}

Even if the patronage of Śaiva religious institutions was not yet a ubiquitous part of the donative repertoire of rulers, the question of who sponsored the Śaiva caves, and why, remains unanswered. Given the paucity of epigraphic evidence from the sites themselves, an historical alternative must be constructed inferentially. This requires returning to the epigraphic records and considering what evidence survives of patronage by groups and individuals outside, or on the peripheries, of the political sphere (i.e. merchant groups, guilds, artisans, village collectives, etc.). Donors from such groups contributed significantly to Buddhist institutions in the North Konkan and Deccan in the early centuries CE. In inscriptions from the North Konkan Buddhist site

and paramamāheśvara, suggesting affiliations with both Buddhist and Śaiva communities (G. Bühler, "Additional Valabhî Grants, Nos. IX-XIV," IA 7: 66-86 [66]; "A Grant of King Guhasena of Valabhî," IA 4: 174-76). Beginning in the mid-late 7th century the Śaiva epithet is also adopted by the Gurjara rulers beginning with Dadda III and Jayabhața III (Mirashi, CII 4, liv). Sendraka Allaśakti also professes to be a devotee of Maheśvara in his Kasare Plates (K.S. 404; 653 CE), CII 4, no. 25, Plate XVIII.

62 Annette Schmiedchen similarly concludes that there is little evidence for the patronage of Śaiva groups by rulers in these regions. Exceptions being the aforementioned Sendraka grant of Allaśakti, which records the donation of land to a Yajurvedic brahmin to support the worship of a local form of Śiva called Alanghyeśvara and a Cālukya grant by Dharāśraya Jayasiṃha to support worship of Śiva under the name of Kāpāleśvara. Schmiedchen, "Patronage of Śaivism," 355-356.

63 Cecil, "Power and Piety," 222-224. 
of Kanheri, for example, merchants, traders, and craftsmen are mentioned as donors, along with the monastic residents themselves. ${ }^{64}$ Although the inscriptions at Kanheri largely predate the supposed mid-6th-early 7 th century date of Elephanta, the preceding pages have shown that trade and commerce in the area had not significantly diminished, as has been assumed. Given the relative stability of the region's economy, it is possible that these well-established patronage networks and patterns sustained the Śaiva community as well.

As the preceding chapters have demonstrated, merchants, traders, and other collective bodies held positions of considerable influence in the early medieval period and they were instrumental in the support and management of temples. Religious giving and the growth of temple centered practices forged connections between 'local' people and broader, supra-local networks and institutions. That the cave temples of the north Konkan supported these kinds of social networks accords with the patterns observed in the surrounding area, as well as with the patterns of patronage that can be observed in later records from the 9 th and 1oth centuries. ${ }^{65}$ I provide a few summary examples below.

The late 6th century Charter of Viṣnuṣeṇa (VS 649/592 CE) ${ }^{66}$ affords valuable insight into the dynamics of power that existed between local economic organizations and rulers and highlights the degree of influence that the merchant community enjoyed in this area. Composed by a local ruler who would have been a contemporary of the Kalacuris, this inscription comprises a list of seventy-two allowances made for a merchant community in Lohāțakagrāma, a village in southern Gujarat - perhaps the ancient port of Lothal, approximately $150 \mathrm{~km}$ northwest of Broach on the Gulf of Khambhat. This extensive list of

64 Lüders, "List of Brāhmī Inscriptions," nos. 984-1034. Many of these donors were residents of the nearby ports - Kalyan, Chaul, and Sopara are mentioned in the donative recordsand from the Deccan around Nasik. Their gifts included money, agricultural tracts, and they sponsored construction projects of water cisterns and halls.

65 For example, a series of records from the port of Sanjan records the creation and maintenance of a Devi matha. Endowed by a family of brahmins at the beginning of the 1oth century, the administration of the mața also involved the local governor of Arab origins, Madhumatī. Since Madhumatī is further qualified as tājikānvaya (of Arab descent, in Verse 17), Sircar is no doubt correct in understanding this name as a Sanskritized version of Muhammad. In his duties, Madhumatī was assisted by collectives of goldsmiths, stonemasons, carpenters, and others. See Cecil, "Power and Piety," 219-220; D.C. Sircar, "Rāșțrakūṭa Charters from Chinchani," EI $3^{2}$ (1957-8). 45-76.

66 D.C. Sircar, EI 30: 163-181; D.D. Kosambi, "Indian Feudal Trade Charters," Journal of the Economic and Social History of the Orient 2 (1959): 281-293. The charter was then ratified in K.S. (605 AD) by another local ruler in the area. We may also infer the proximity of Lohāțā to a port from the mention of various taxes levied on goods carried by boat in regulations 53-61. See also Harald Wiese and Sadananda Das, The Charter of Viṣnuṣena (Halle: Universitätsverlag Halle-Wittenberg, 2019). 
rules and regulations insured the merchants' autonomy, their ability to engage in trade without restrictions and taxes, and freed them from obligations to rulers and local landowners. ${ }^{67}$

In addition to reflecting the autonomy of merchant communities, a set of early 6th century copper plates from Sañjeli in southern Gujarat show clearly the extent to which economic actors and local collectives were involved in the religious life of the area. ${ }^{68}$ These records make provisions for the support of a local Viṣnu temple dedicated to the deity Jayasvāmī. The temple was endowed by Virādhyikā, the mother of local ruler Mahārāja Mātṛdāsa, but the records show that the maintenance and support of this religious center involved people from various social strata and economic means. The first plate mentions donations by a group of local residents and foreign businessmen - coming from as far as Daśapura, Ujjain, and Kanauj-who agree to impose certain taxes on non-prestige goods (i.e. molasses, salt, cotton, and grain) to support worship at the temple. ${ }^{69}$ This was done for the increase of their own religious merit. The temples in this area were clearly important loci of social interaction between merchant groups, both local and supra-local, craftspeople, agriculturalists, as well as political elites. In addition to the various pilgrims, religious specialists, and temple servants who resided on the temple grounds. ${ }^{70}$

In the village of Jayapura near Anjaneri in the Nasik District, ${ }^{71}$ Bhogaśakti, a ruler from a branch of the Cālukya family, issued two sets of copper plates along with an affiliated officer named Tejavarmarāja in $710 \mathrm{CE}$. In the first set of plates, Bhogaśakti donates eight villages to the temple of Nārāyana called Bhogeśvara. The naming of the deity after the local ruler memorializes him and his pious donation. The care of the enshrined deity, temple, and its property

67 For example, the first item (Lines 1-2) concerns the inheritance of property and ensures that property of one without an heir would be inherited by the guild rather than by a local ruler. Lines 11-13 state that guild members would not be required to pay taxes and dues to rulers, nor could they be called to labor for the rulers without pay. Line 24 prohibits the seizure of peasants traveling to markets by rulers or local landowners for labor in their fields. The inscription also records some of the duties and requirements for guild members along with detailed lists of the permissible taxes on different kinds of merchandise from bamboo to wine (Lines 25-72).

68 R.N. Mehta \& A.M. Thakkar, M.S. University Copper Plates of the Time of Toramana (Vadodara: M.S. University Archaeology Series 14, 1978); K.V. Ramesh, "Three Early Charters from Sanjeli in Gujarat," EI 40 (1973-5): 175-186.

69 Mehta \& Thakkar, University Copper Plates, 14 (plate of regnal year 3), lines 3-4.

70 These people are mentioned in lines $3-5$ of the plate of regnal year 6 , which specify provisions to be made for their care and special meals. Mehta \& Thakkar, University Copper Plates, 15 , lines $3-5$.

"Anjaneri Plates (First Set) of Bhogaśakti: K.S. 461" (709/10 or 710/11 CE), CII 4, 146-153. 
is then entrusted to the collective body of the town's merchants. The inscription also mentions that the interest acquired from the rental of temple-owned lands was to be used by the same collective to supply incense for the temple rituals. $^{72}$ A contemporaneous inscription from nearby Thane in the North Konkan records similar modes of corporate patronage. The Mānor Plates dated (SS 671/749-50 CE), praise the donation of a village to the Siva temple of Bādeśvara by a collective (mahājana) of local brahmins. ${ }^{73}$ While the donors acknowledge the sovereignty of the Rāșțrakūța ruler Dantidurga, the king was not involved directly in the endowment.

\section{3 Śaiva Spaces in the North Konkan}

Understanding the North Konkan caves as the work of diverse networks of donors and patrons aids in analyzing the structure and execution of the area's three prominent cave complexes-Jogeśvarī, Mandapeśvar and Elephanta. The articulation of these spaces is evidence of the different social purposes they served and the communities that they supported. While drawing attention to the unique features of each excavation, the discussion that follows also emphasizes continuities in their artistic features and style. This aesthetic resonance could reflect the work of an atelier of artists active in the region for generations. In contrast with previous studies of the caves that assume a chronological frame in which the sites operated in chronological successionJogesvarī as the oldest, followed by Maṇapeśvar and Elephanta—I argue that their shared iconographic themes and idioms provide a strong case for viewing these monuments as broadly contemporaneous institutions within a shared religious landscape. ${ }^{74}$

72 In the second set of plates from approximately the same time, Bhogaśakti granted additional privileges to the merchant communities in villages under his jurisdiction ("Anjaneri Plates (Second Set) of Bhogaśakti," CII 4, 154-159). These inscriptions are not dated, but based on the repeated mention of Tejavarmarāja from the first Anjaneri inscription, Mirashi concludes that these two sets of plates were composed around the same time. Mirashi, CII 4, 156.

73 V.V. Mirashi, "Mānor Plates of Rāșțrakuța Dantidurga: Śaka Year 671," Indian Historical Quarterly 35 (1959): 183-188.

74 Rajan, Cave Temples of the Deccan; EITA 2.1, 85-92; Spink, "Monuments of the Early Kalacuri Period"; Spink, "The Great Cave at Elephanta"; Collins, Śiva at Elephanta. 


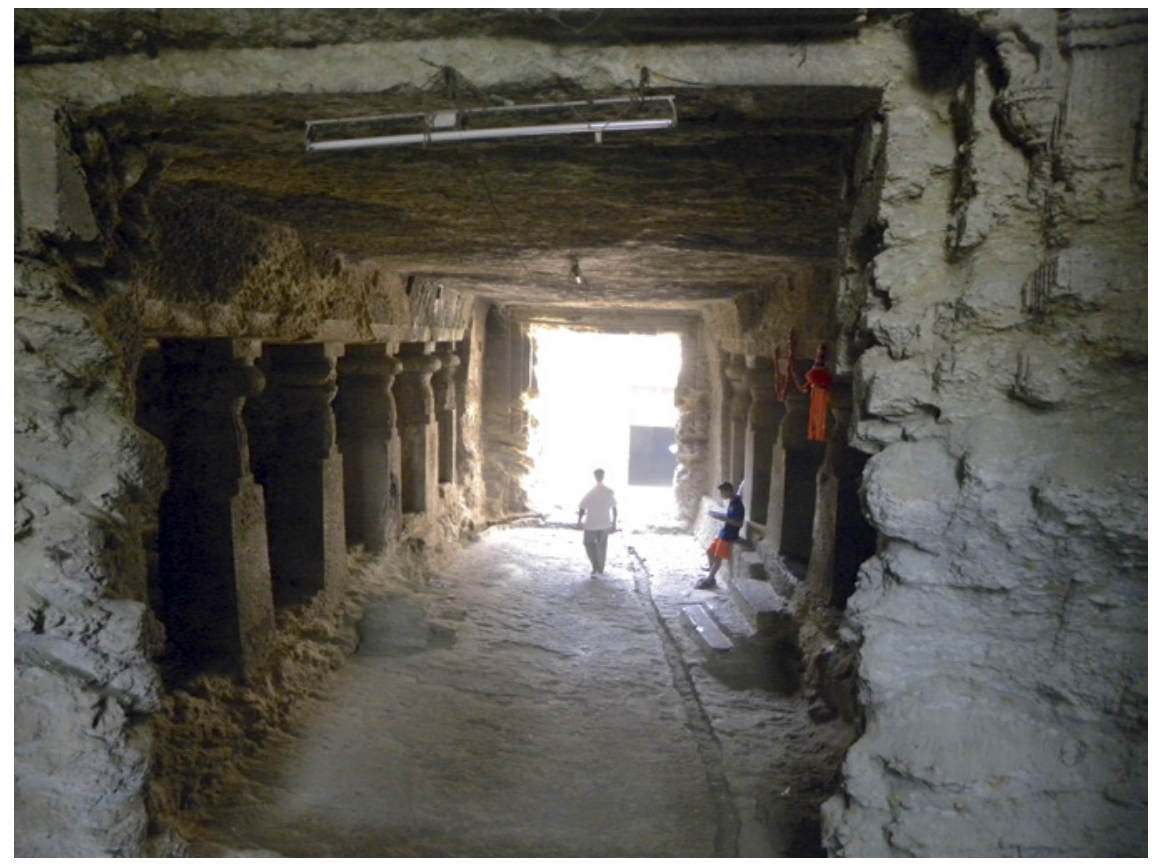

FIGURE 73 Approach to Jogeśvarī caves

\subsection{Tracing a Pāśupata Presence:Jogeśvarī}

Of the three North Konkan sites, the cave complex at Jogeśvarī is the largest and, in many respects, the most complex of the three sites. And, perhaps of greatest significance for this study, Jogeśvarî is the only one of the three cave temples that preserves compelling evidence for a Pāśupata affiliation. The caves are oriented along an east-west axis, with the primary access point being the east descent [Figure 73]. That the east was intended to be the main entrance is clearly articulated by the structure of the monument and accompanying iconographic program, which guide the devotee through a series of entryways punctuated by important iconic scenes from the mythology of Siva. This extended processional path into the center of the cave structure culminates with the central linga shrine. The first doorway is framed by a Rāvañanugrahamūrti panel, now largely destroyed. The visitor then enters a long hall with subsidiary shrines on each side framed by a series of pillars. On the left, there are faint traces of a Mātrkā panel, which can be inferred by the series of areolae and the remaining female head with a child's head on the proper lower left side. Opposite the Mãtrkās, on the other side of the hall, are three panels of which only the Ganeśa in the central niche can be clearly identified. The image is under active worship [Figure 74]. Images of Durgā and Skanda may have 


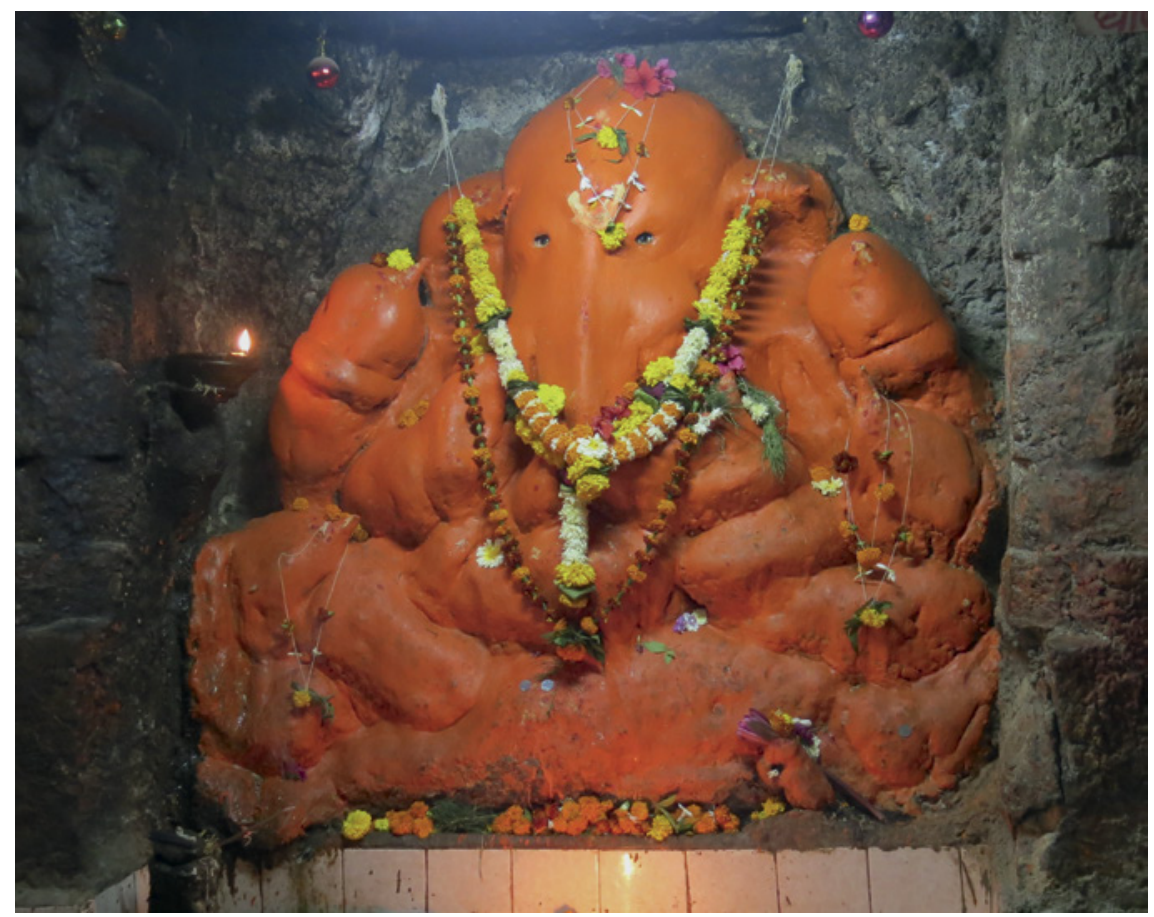

FIGURE 74 Gạ̣eśa shrine, Jogeśvarī caves

occupied the spaces to the left and right, respectively, of Ganeśa, but these are too damaged to identify clearly. ${ }^{75}$ The inclusion of these deities within a space so clearly framed as Śaiva serves to integrate them, and presumably their worship, within the monument as a whole. The next doorway is framed by a dancing Śiva, with two kneeling figures visible in the foreground. On either side an extended scene was carved, but only three stout ganas on the left remain. Passing through the final entryway the devotee again encounters images of important mythological scenes: the depiction of the wedding of Śiva and Pārvatī, and the couple playing dice [Figures $75 \& 76$ ].

Much of the rich iconography in the caves has been eroded by water and lost due to the porosity of the stone, making it difficult to reconstruct the full

75 The sculptures in the panels to the left and right of the Ganeśa are heavily damaged. The far left may have contained an image of Durgā, as Collins suggests. An image of Yogeśvara is a second possibility — there are remains of what looks like a human torso seated on a kind of pedestal. The right contained a standing male figure with three smaller figures positioned in front. One of these smaller figures has a goat's head, perhaps Naigameșa. An image of Skanda with attendants could have occupied this panel. See Collins, Śiva at Elephanta, Figure 85 . 


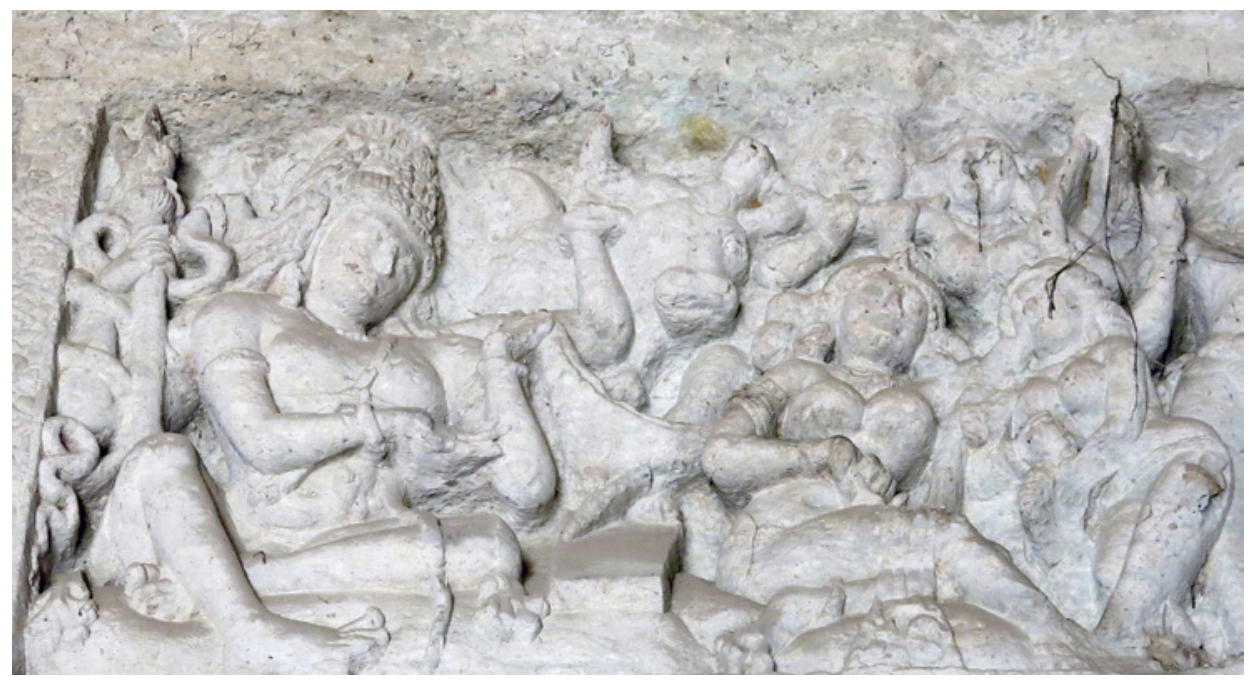

FIGURE 75 Panel depicting Śiva and Pārvatī playing dice, Jogeśvarī caves

program. The spatial articulation of the excavation, however, allows for a partial reconstruction of the physical experience of the site. The prolonged approach and descent accentuate the experience of entering a cave and the multiple entryways with their carved architraves encourage the visitor to pause and linger at these junctures. The carved panels in the pillared hall similarly encourage the visitor to stop, and they contribute to the slow and graduated flow of the monument as a whole. The incorporation of smaller shrines to Ganeśa and the Mãtrkās in an ancillary space, preceding the main linga shrine, gives spatial expression to a divine hierarchy. These deities are included within the cave's pantheon, but the central shrine is reserved for Śiva. We might assume that the deities depicted in these large panels would have been subjects of individual worship and ritual practices, much as the Ganeśa image remains a focus of püjā today.

After processing through the entries and ancillary shrines, the visitor arrives at the inner sanctum, where the Pāśupata affiliation is expressed visually. The ling a shrine is framed by two images of Lakulisśa. One appears in the doorframe to the main (east) entrance. The other is carved on the west side of the linga shrine [Figure 77]. In the image that frames the shrine on the east side, the teacher is shown surrounded by four figures who may have been intended to represent his four students. While I earlier suggested that the textual icon of 


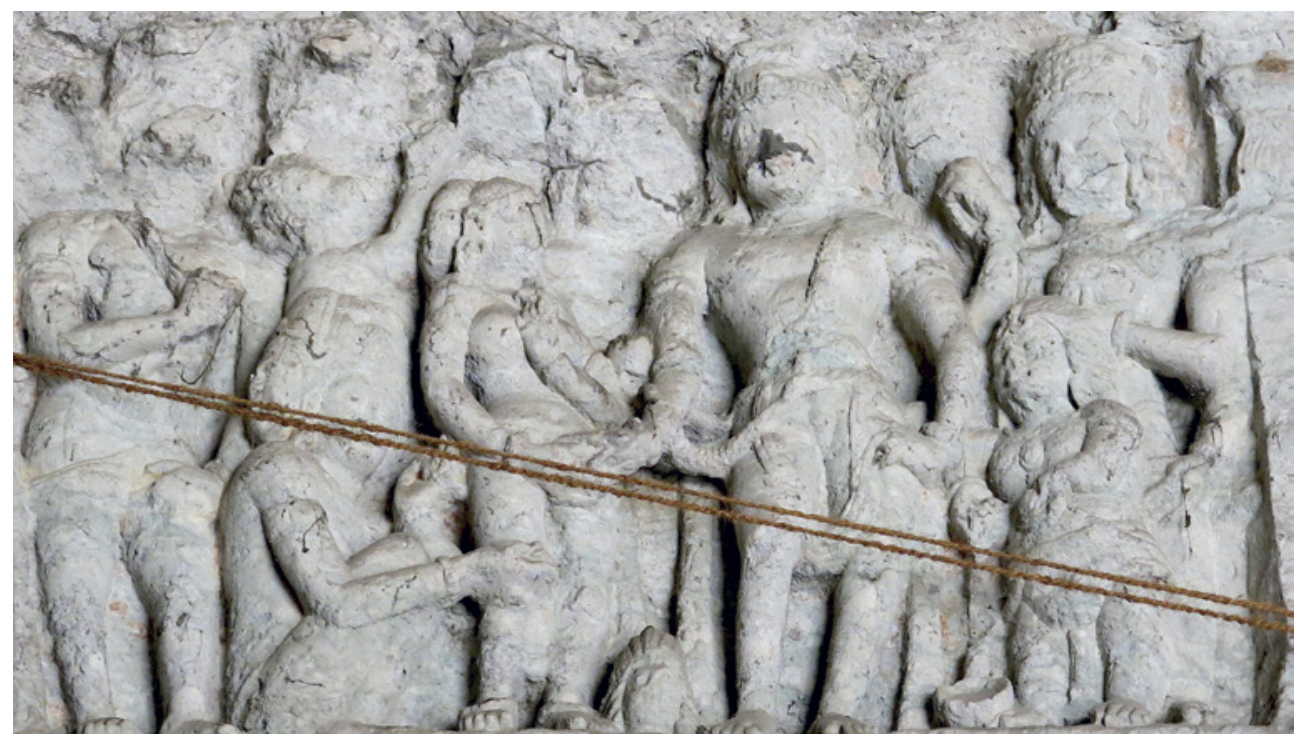

FIGURE 76 Panel depicting wedding of Śiva and Pārvatī, Jogeśvarī caves

the four students in the SP gestures to a kind of totality or visual plenum, I think we can see a comparable idea articulated visually in this icon. The inclusion of the four surrounding figures creates a totality or a 'set.' The fact that these accompanying figures are not depicted in exactly the same way also indicates a certain diversity within this set. I would suggest that these figures were intended to represent not only Lakulīśa's students, but different registers of the Pāśupata community as well. The figures in the upper left and right corner appear aged and their beards and matted hair suggest asceticism. By contrast, the figures in the foreground appear youthful and they do not bear ascetic marks. Perhaps these two represent a younger generation of initiates or even laypeople. The image of Lakuliśa here is also unique. He projects a powerful physical presence and, notably, he does not appear to be ithyphallic. Thus he is absent one of Lakuliśa's key iconographic features that is also a significant marker of the Śaiva ascetic. The image is a synoptic icon, a visualization of the community that gestures to a totality while also acknowledging the internal diversity of the community. The Lakuliśa on the back of the shrine is shown alone and framed by a floriated arc. It is also worth noting that this icon is not ithyphallic. 




FIGURE 77A Lakulīśa with four attendants, Jogeśvarī caves

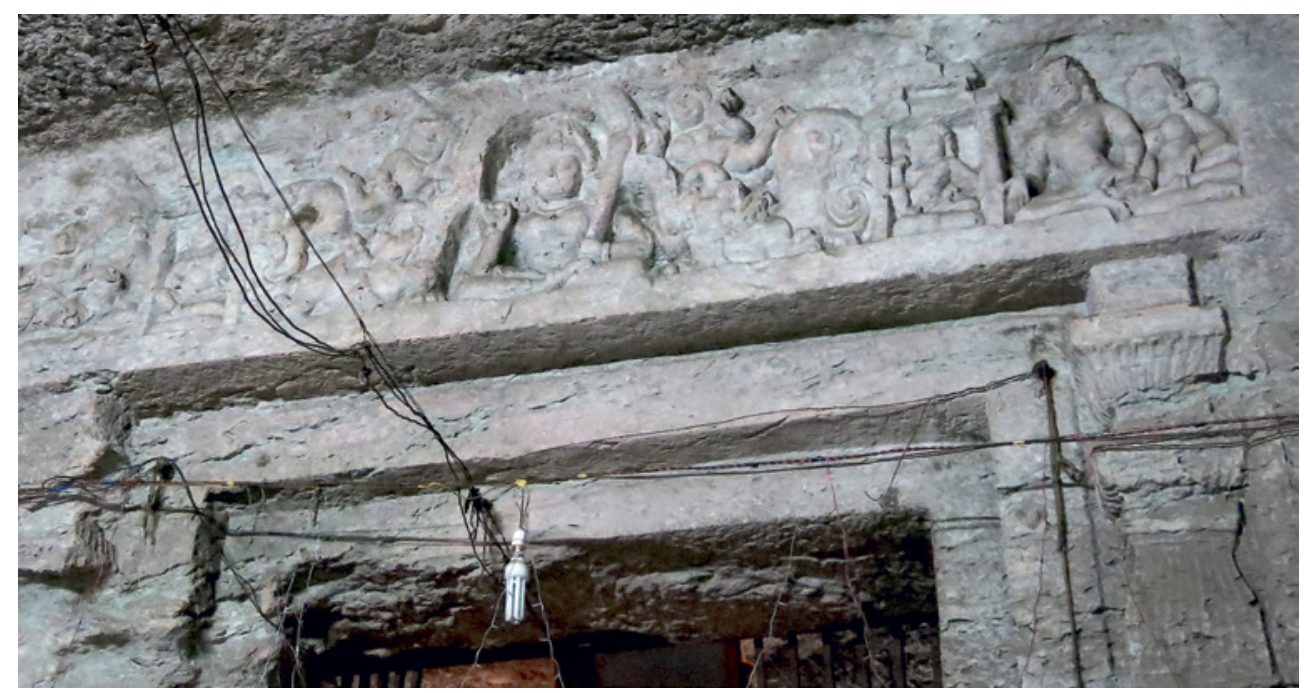

FIGURE 77B Lakulīśa, west side of linga shrine, Jogeśvarī caves 


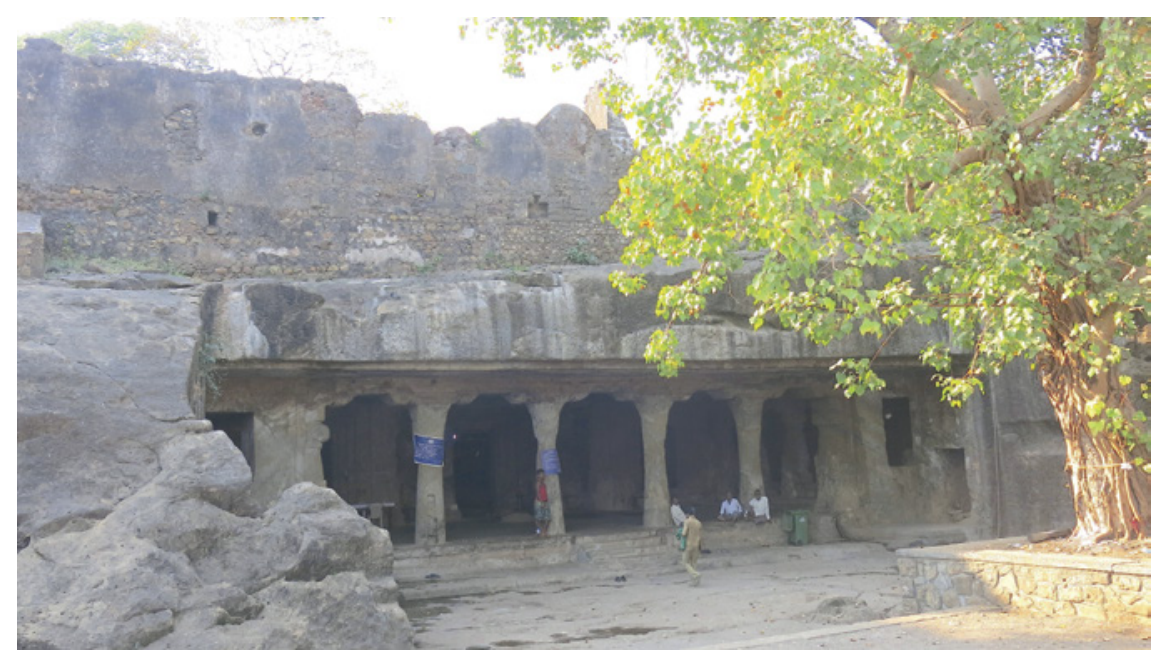

FIGURE 78 Exterior of Mạ̣ḍapeśvar caves

\subsection{Maṇdapeśvar and Elephanta}

While the Jogeśvarī temple is gradually revealed as the visitor is slowly ushered through the cave, the temples of Mandapeśvar and Elephanta are articulated in a very different manner. Rather than using the cave to heighten the experience of interiority, these sites oppose the physical confines of the rock to create more open and accessible spaces. Mandapeśvar is a relatively simple excavation framed by a pillared hall [Figure 78]. The main cave at Elephanta, a far grander and imposing a monument in scale, displays a similar concern for openness and movement.

In their iconography, the three North Konkan sites depict many of the same key mythological tableaus. For example, the icon of the dancing Śiva, which appeared above the second doorframe at Jogeśvarī also appears, and is rendered in remarkably similar fashion, at Maṇdapeśvar and Elephanta [Figure 79]. The Mātrs are incorporated prominently within the program at Elephanta as well. Charles Collins has explored the overall iconographic programs and stylistic resonance between these sites in great detail. Yet, for all their shared artistic features, neither Elephanta nor Mạ̣dapeśvar present compelling evidence of a Pāśupata presence. I do not agree with Collins' identification of the Yogeśvara icon, located in the west wing of the main cave at Elephanta, as Lakulissa since there is no clear indication that the figure held a club. ${ }^{76}$ Mandapeśvar, however, does include a Lakuliśa [Figure 8o], but the position and presentation

76 Collins, Śiva at Elephanta, Figure 18. 


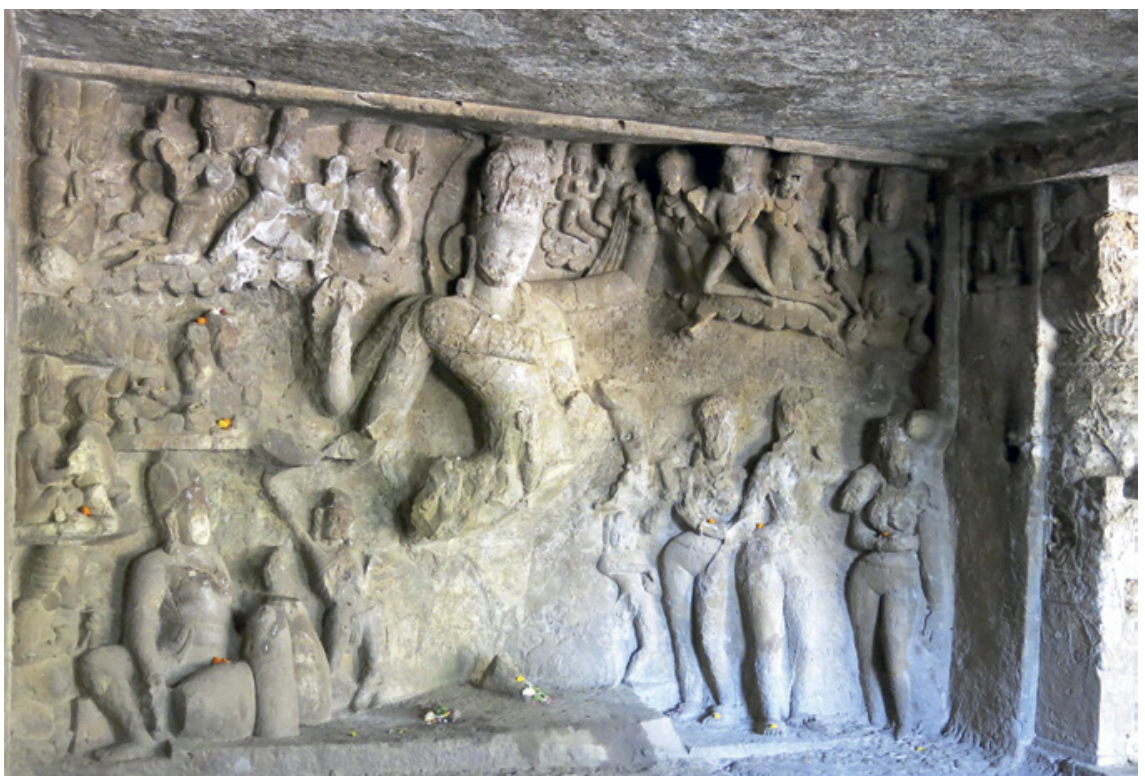

FIGURE 79 Śiva Națeśa panel, Maṇḍapeśvar caves

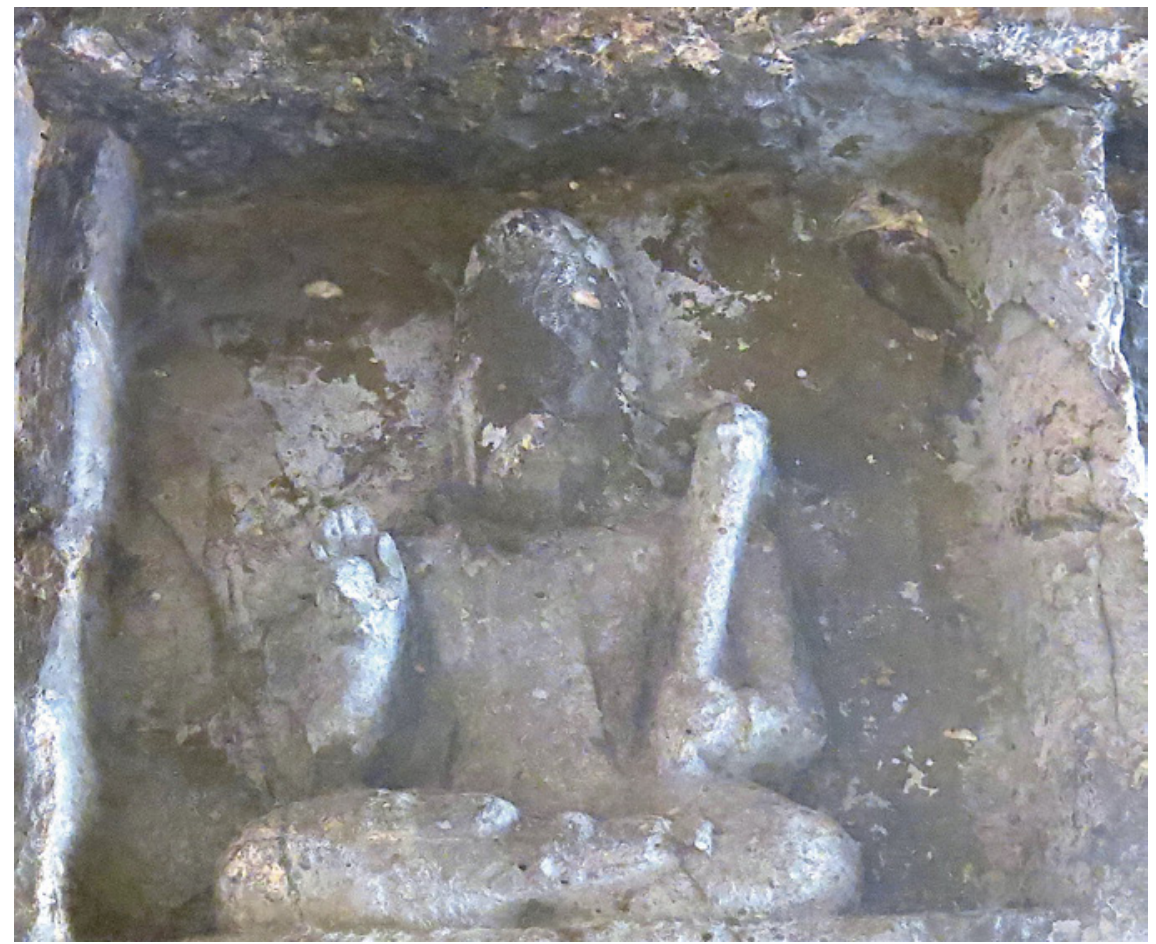

FIGURE 80

Lakulīśa, Maṇ̣apeśvar caves 
of the image suggest that it was not a significant component in the overall program at the site. For one, the 'cut-in' technique used to carve this sculpture is different than the relief style of carving in the other panels. This difference in execution could indicate that the image was carved at a different time; that is, it was not conceived as part of the program. And rather than occupying a place of prominence over the linga shrine, as we saw in the case of Jogeśvarī, at Maṇ̣apeśvar Lakulisśa appears as an iconographic afterthought, nearly hidden on an interior wall adjacent the dancing Śiva panel. Locating a Pāśupata presence in the North Konkan clearly requires further consideration. It is evident that both Manḍapeśvar and Elephanta were important places for the early medieval māheśvara community, along with other locales in the vicinity like Parel, where monumental images of Siva were recovered. Despite the popularity of Śaivism in the early medieval North Konkan, only Jogeśvarī presents us with compelling evidence for a Pāśupata affiliation.

\section{Alternative Cartographies: Śaiva Centers in the Deccan}

A single theory is not sufficient to explain the geographic distribution of both the North Konkan and the Deccan sites. Unlike the North Konkan caves, the Deccan Śaiva centers do not align as easily with the major caravan routes. The clusters of rock-cut caves in the hinterlands were dispersed much more widely, often at a considerable distance from one another and from the major trade routes. The pages that follow offer only a preliminary analysis since the material is too copious and the geographic range too expansive to permit a detailed treatment at this stage. The discussion following presents the Deccan sites as an illuminating set of comparanda that supports my hypothesis about the North Konkan by showing how the growth of Śaivism was shaped by regional geographies.

The connection between Buddhist centers and trade is also less apparent in the Deccan than in the North Konkan, and efforts to argue such linkages display a certain degree of circularity: since the Buddhist caves of the Deccan are assumed to have developed along trade routes, the presence of a Buddhist cave site is thus taken to indicate the presence of a trade route. ${ }^{77}$ The major Buddhist sites are not always positioned along the most direct or geographically accessible routes between the market towns and settlements, but since Buddhist sites are taken as "fixed points" on the route, they must be accommodated 
within the itinerary. ${ }^{78}$ As Kathleen Morrison has noted, remains of Buddhist centers are conspicuously absent from the Sătavāhana political centers of the Deccan, like Paithan. ${ }^{79}$ This contrasting pattern in the siting of religious centers (both Buddhist and brahmanical) conveniently along the major routes does not mean that these places were isolated from economic networks. Local and regional routes would have provided alternative channels. Evidence from archeological excavations at Deccan sites like Kaundinyapur, Shisupalgar, and Nevasa also highlights the vitality of localized patterns of mobility. Analysis of the material evidence shows that while these hinterland areas were not cosmopolitan centers for the exchange of exotic or 'prestige goods,' short-distance trade flourished..$^{80}$ In terms of how they are embedded within the physical terrain, however, the Deccan sites were, like their North Konkan counterparts, placed in elevated areas and nearby water sources. And like the coastal caves, systems of water collection and storage suggest the important social function of these sanctified spaces, particularly in the dry season.

\section{1 Śaiva Caves? Questions of Community and Identity}

The Deccan sites have garnered far less scholarly attention than the Konkan caves. This is, in part, because they are not as well preserved and because their artistic features make an easy classification impossible. The most important recent study of the region is Pia Brancaccio's work on the Aurangabad caves,

78 Chakrabarti, Deccan Routes, 65.

79 Kathleen Morrison, "Trade, Urbanism, and Agricultural Expansion: Buddhist Monastic Institutions and the State in the Early Historic Western Deccan," World Archaeology 27.2 (1995): 203-221, 216. P.K. Reddy also challenges the idea that Buddhist sites were located consistently along trade routes and similarly calls for consideration of other factors influencing the development of the Buddhist landscape in Andhra. Reddy, "God, Trade, and Worship: A Glimpse into the Religion of Early Āndhradeśa," East and West 48.3 (1998): 291-311.

8o For example, Monica Smith's analysis of ceramics from Kaundinyapur shows that the region developed its own traditions of pottery making. Summarizing the results of her excavation, Smith concludes, "it is not surprising that pottery and other durable goods were made of local materials rather than transported hundreds of kilometers from the coasts. The trade networks of central India were constructed primarily to meet the local demands with regional materials, and did not depend on coastal peoples for any but the most exotic of goods (such as shell for bangles)." This evidence suggests that regional networks of exchange contributed a significant amount of the daily use and household goods excavated at the site. Monica Smith, "Systematic Surface Survey at the Early Historic Site of Kaundinyapur, India," Man and Environment 25.1 (2000): 75-87; The Archaeology of an Early Historic Town in Central India (Oxford: British Archaeological Reports International Series 1002, 2001). The results of these surveys relating specifically to trade are summarized in Monica Smith "Role of Local Trade Networks in the Indian Subcontinent," Man and Environment 27.1 (2002): 139-151. 
which provides an illuminating study of Buddhist religious life at the site. In her discussion of patronage in the Deccan, Brancaccio relies on Spink's Kalacuri hypothesis and concludes, based upon stylistic connections between Konkan monuments and those of Aurangabad, that the "early Kalacuri dynasty may have functioned as a bridge between these regions not only for the diffusion of a new visual idiom but also for the dissemination of the Śaiva ideology it expressed." ${ }^{81}$ While stylistic analysis may indeed point to connections between the Aurangabad and North Konkan caves, inferring the movement of artisans and ateliers provides a more likely explanation than political activities of the Kalacuris. Further, Rajan's useful analysis of stylistic connections between the Deccan sites and those further south is an indication that this region was an artistic crossroads, preserving traces of multiple influences and inspirations. ${ }^{82}$

Since we lack documented evidence for patronage at any of these sites, and the Kalacuris have been discussed at length above, in this final section I focus on what the organization of these spaces and the variety of religious imagery preserved might reveal about Śaivism in the early medieval Deccan, looking specifically at evidence from the caves at Aurangabad, Bhokardhan, and TakliDhokeśvar. When compared with the iconography of the North Konkan caves, those of the Deccan show a greater degree of diversity and eclecticism. In the North Konkan sites, the high level of skill displayed in the carving and the relatively univocal presentation of the iconographic program, in which key scenes from Śaiva mythology were repeated across the three sites, suggests that this region was developing a Śaiva religious community as distinct from among the larger religious milieu. In contrast, the Deccan caves reflect a more multivocal religious identity in which quotidian concerns for protection, fertility, and prosperity are foregrounded. The absence of Lakuliśa images at these sites also suggests that these places were not integrated within a Pāśupata network.

\subsection{The Brahmanical Cave at Aurangabad}

The so-called 'Brahmanical cave' in the series of cave temples on the outskirts of Aurangabad preserves important traces of a shared religious landscape. The Aurangabad cave complex was part of the extensive network of such Buddhist sites in the Deccan, such as the well-known caves at Ajanta and Ellora.

81 Pia Brancaccio, The Buddhist Caves at Aurangabad (Leiden: Brill, 2010), 205. For an overview of similar patterns in scholarship on Ellora's patronage see Lisa N. Owen, Carving Devotion in the Jain Caves at Ellora (Leiden: Brill, 2012), 160-163.

82 In Rajan's catalogue, these sites are connected with the patronage and influence of the Cālukyas - albeit somewhat tentatively qualified as 'Provincial,' a designation that distinguishes them from the royal centers like Ellora or Bādāmi. Rajan, Cave Temples of the Deccan, $160-167$. 


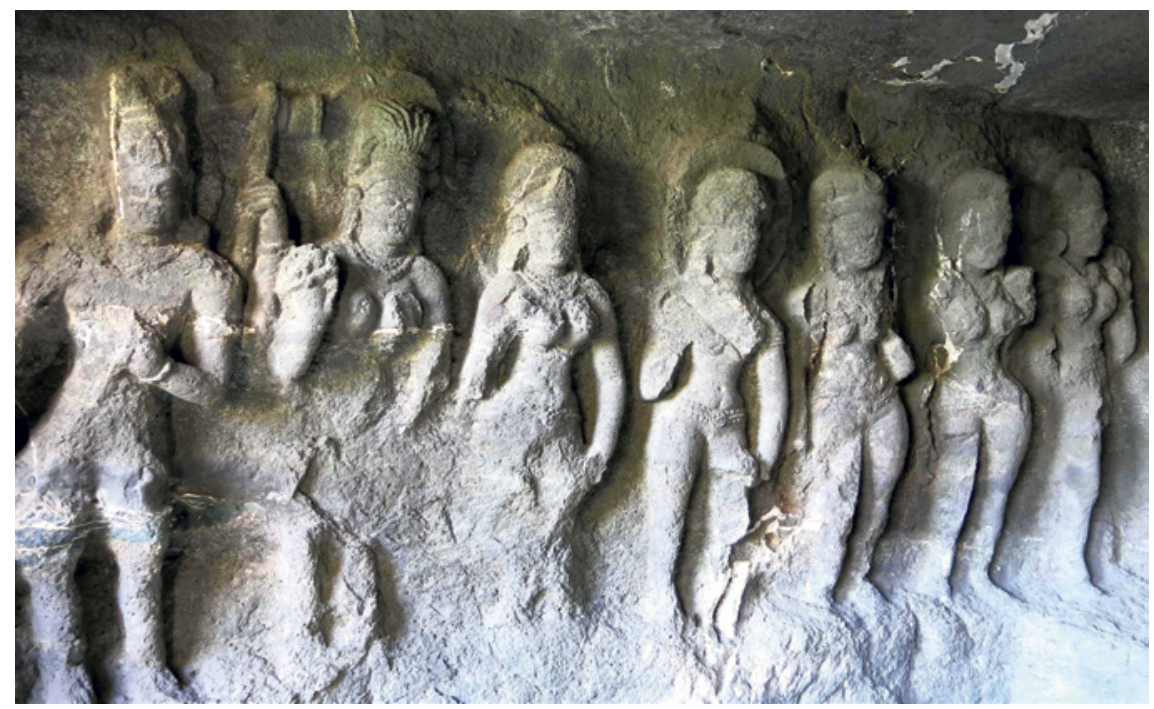

FIGURE 81 Aurangabad, Brahmanical cave, 6 of the Saptamātrkās with Vīrabhadra

The series of nine completed caves occupy the western and eastern faces of the hills and were excavated between the late 4 th and early 7 th centuries $\mathrm{CE} .{ }^{83}$ Only one of these caves in the eastern group contains iconographic evidence of brahmanical and, more specifically, Śaiva-related religious activity. The front-facing wall contains a large image of Ganeśa and an image of Durgā Sim havāhini on the proper left side of Ganeśa. The left interior wall contains a large panel depicting the Mātrrs flanked by Śiva as Vīrabhadra. Perhaps due to a lack of space, the image of Cāmuṇ̂a is carved on the adjacent wall to the right side of Ganeśa [Figure 81]. This simple cave shows evidence of a series of additions over time; for example, in the different carving styles used to create the two Buddha images seated in padmāsana in the right interior wall: one placed upon a projected platform and the other, adjacent image, now severely damaged, is a set-in carving [Figure 82].

In his analysis of the iconographic program, Rajan interprets the inclusion of the Saptamatrtrā panel as evidence of the superseding of Buddhism by the brahmanical tradition. He comments, "The importance of the cave would perhaps lie in the fact that it presents a striking evidence of a supplanting by brahmanical art of the Buddhist in the same cave, thus marking the twilight

83 I have followed the chronology and dating of the caves proposed by Brancaccio, Buddhist Caves at Aurangabad. 




FIGURE 82 Aurangabad, Brahmanical cave, sculpture of the Buddha

hours of Buddhist activity at Aurangabad and around Ellora [...]"84 Rajan's assessment that Buddhist activity was in a state of decline in the Western Deccan by the end of the 7 th century may be accurate, but the language of 'supplanting' is too strong in this case. The presence of Śaiva-related deities in a single cave of a much larger Buddhist complex does not seem sufficient evidence to infer

84 Rajan, Cave Temples of the Deccan, 157. 
a general dominance of the brahmanical pantheon over the Buddhist. ${ }^{85}$ The placement of the Ganeśa image in the center of the front panel is suggestive of a hierarchy, as the devotees' eyes would fall first upon this deity. But the images of the Buddha on the right side remained undisturbed, a suggestion that the engagement with the Goddesses, their accompanying members of the Śaiva pantheon, and the Buddha did not present a problematic incongruity to the visitors who used the space. ${ }^{86}$ Brancaccio similarly characterizes the relationship between the Śaiva and the Buddhist communities as essentially agonistic and she interprets the prominence of the Buddhist deity Vajrapāni within the sculptures of the eastern caves as evidence of a Buddhist iconographic retaliation (via the militant deity) to a growing Śaiva presence. ${ }^{87}$ Yet the fact that Vajrapāni's iconography incorporates characteristic Śaiva elements (snake armlet and àyudhapuruṣa) suggests a dialogue rather than a confrontation. Alternatively, we could interpret the iconographic program in this cave as important evidence of a shared and even competitive ritual space rather than an overtly hierarchical expression of Brahmanism over Buddhism.

In her work on the site, Brancaccio has also emphasized the strong presence of a diverse Buddhist lay-community, traces of which she observes in the incorporation of images of Lajjā Gaurī, in the repetition of votive panels, and in the artistic depiction of lay devotees, many of them women. ${ }^{88}$ In a similar vein, the inclusion of the Śaiva Mātrkās is not anomalous if we also consider the iconography of the surrounding caves on the eastern slope and the prevalence of female deities in them. In Cave 7 , for example, a sculpture of Avalokiteśvara is depicted with six accompanying goddesses with lotuses and an image of the Buddha in the gesture of granting boons (varadamudrā). Brancaccio identifies these females as the six vidyārājñis, goddesses associated with the power

85 In her study, Brancaccio also comments on this anomalous cave and the challenges posed by its iconographic program, as well as its place within the larger chronology of the Aurangabad caves. (Buddhist Caves at Aurangabad, 202.)

86 At the time of Rajan's work both of the Buddha images in the cave were intact and largely undamaged. This has changed since, at the time of my visit in 2013, one of the images had been badly damaged.

87 "The growing popularity of Vajrapāni in the caves of the western Deccan during the sixth century may be directly linked to the growing challenges that Buddhism faced in the area from the Śaiva tradition, strongly supported by the Kalacuris and the feudal elite at the time. In order to survive, Buddhism had to come to grips with the other religious traditions and use all weapons available, including Vajrapāni's vajra to protect the dharma and those that opposed it." Brancaccio, Buddhist Caves at Aurangabad, 171. 
of mantras and magic. ${ }^{89}$ As she also notes, the goddesses of Cave 7 appear "to have been created after the blueprint of the Śaiva Mātrkās." ${ }^{\prime 90}$ This resonance between the Śaiva imagery and the panel of Cave 7 could also indicate a shared set of values (i.e. fertility, protection, etc.) connected to these female figures and reinforced by the images of Avalokiteśvara, the protective deity par excellence, and the wish-granting Buddha.

The groups of Mātrkās or 'mother goddesses' are a feature shared by many, though not all, of the Śaiva caves of the North Konkan and Deccan. Guided by Katherine Harper's work, Laughlin interprets the presence of the Mātrkās as a sign of royal patronage and their presence is one of his criteria for classifying a site as a 'royal' religious center as opposed to a popular center. ${ }^{91}$ But the martial potential inherent in the Mätrka figures, a potential which would have made them attractive to rulers or those seeking power, is, as I have argued in a previous study, an echo of their ambivalent or ambiguous character. ${ }^{92}$ Thus, while the mothers would have been compelling figures for those aspiring to power, we must also acknowledge that these highly charged female figures would have resonated with a much wider audience. As figures intimately connected with the fears and anxieties surrounding fertility, childbirth, and the health and well-being of children, the larger community would have also had been invested in the propitiation of these powerful, but deeply ambivalent females.

\subsection{The Bhokardan Caves}

Approximately $75 \mathrm{~km}$ northeast from Aurangabad another cave complex was excavated at Bhokardan that dates to the mid-7th century. The main series of caves were excavated in a low-lying area on the left bank of the Kelnā River. ${ }^{93}$

89 Brancaccio, Buddhist Caves at Aurangabad, 175-177; citing the Mañjuśrimūlakalpa in which the goddesses are named as Pāṇ̣̣aravāsinī, Tārā, Bhṛkuṭī, Prajñāpāramitā, Locanā, Uṣnịiṣarājā.

90 Brancaccio, Buddhist Caves at Aurangabad, 174.

91 Laughlin, "Kalacuri Monuments," 84-109. Brancaccio also draws a connection to the presence of the Mātrkās and religious sites associated with the Kalacuris and early Cālukyas, implying that the ubiquity of the mothers' images at these places could be evidence linking the rulers to the sites (Buddhist Caves at Aurangabad, 202). However, the popularity of the mātrs at early medieval temples was common throughout northwest India, not only at places associated with these ruling families.

92 Elizabeth Cecil, "Childless Mothers and Rejected Wives: A New Perspective on the Mātrs," Paper presented at the 2011 Annual Meeting of the American Oriental Society.

93 Based upon the excavation reports, the ancient settlement is represented by a series of mounds that spanned both the right and left banks of the Kelnā, where the modern town of Bhokardan is situated. The village of Alapur now sits atop the left bank mounds. S.B. Deo (ed.), Excavations at Bhokardan (Bhogavardhana) 1973 (Aurangabad: Marathwada University, 1974), 6. 


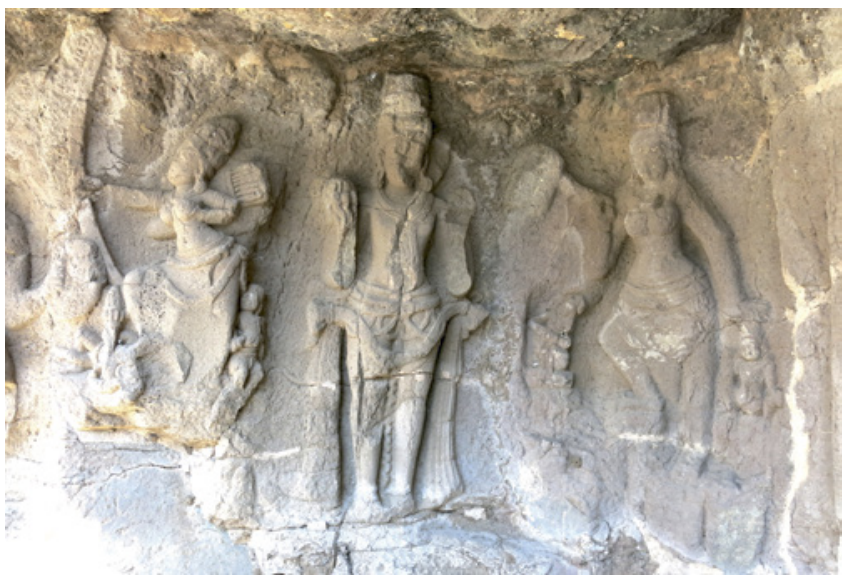

FIGURE 83

Bhokardan caves, carvings in interior showing Durgā,

Sūrya, and female chowrie-bearer

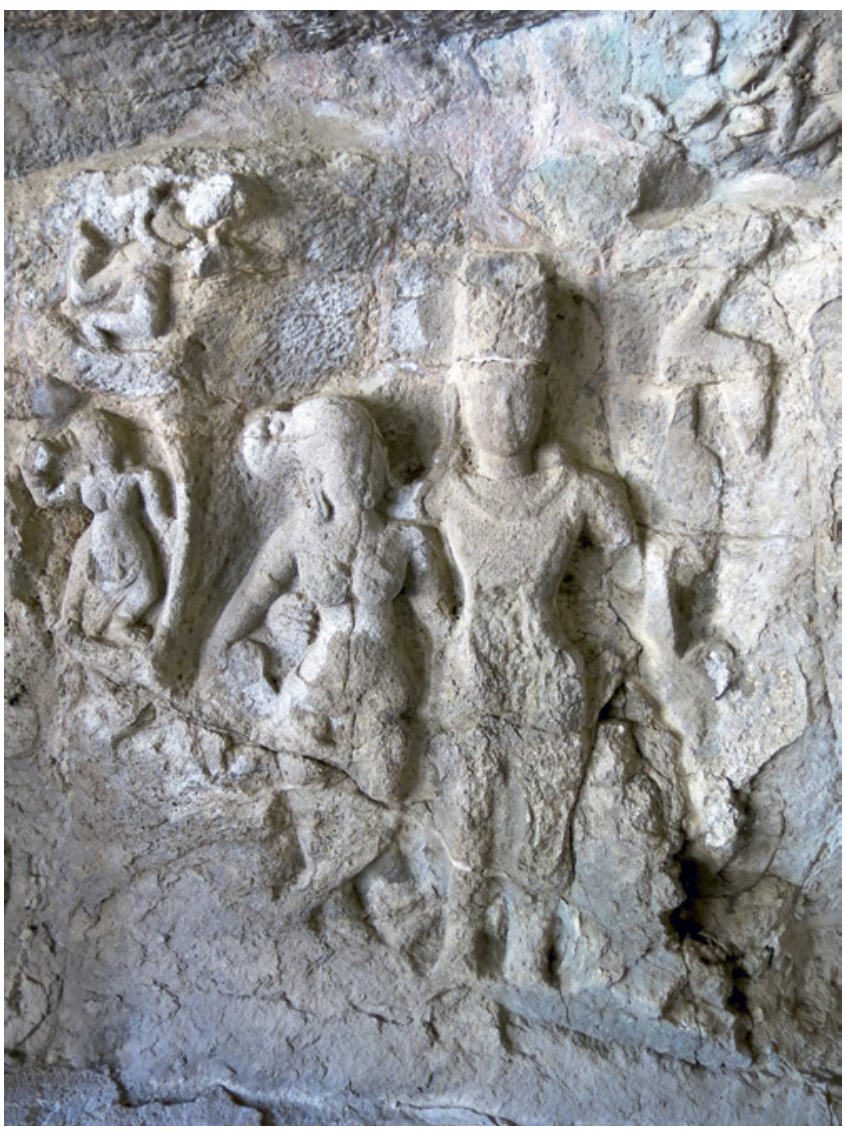

FIGURE 84

Bhokardan caves, carvings in interior showing

Samkarșana and Revatī 


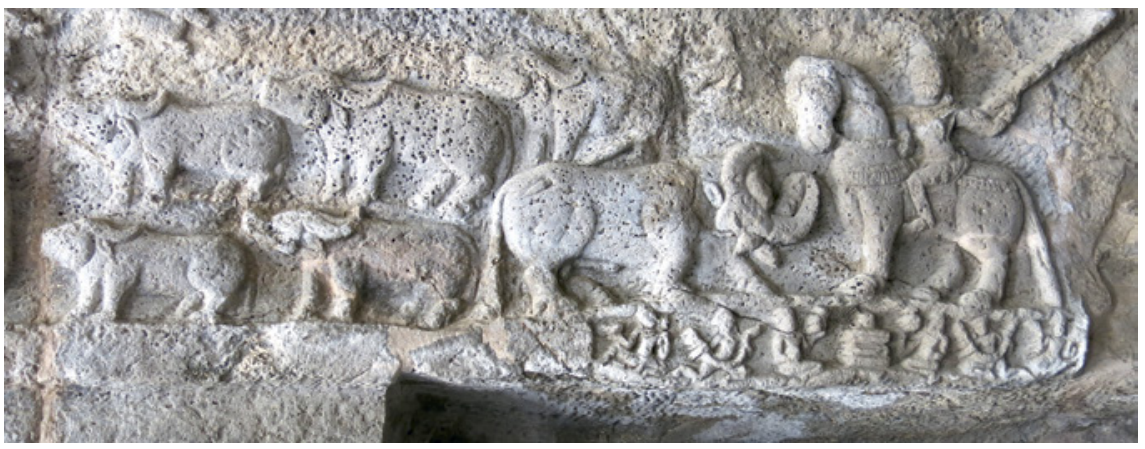

FIGURE 85

Bhokardan, cave entry interior hunting scene and panel depicting linga veneration

Additional caves in varying states of excavation line the rock facing the river. The main excavation consists of a series of seven small shrines, roughly equal in size, approached through an entryway of two rows of six unadorned pillars. The walls on both sides of the entry courtyard are filled with a variety of images carved in relief, some of which can still be identified [Figures 83 \& 84]. No images remain within the seven shrines. The images in the caves represent a variety of Vaiṣnava, Śaiva, and Goddess-centered themes and it may be that the seven shrines housed a variety of such deities as well. Rajan suggests they may have contained an image of Viṣnu in the center and images of Sürya, Durgā, Kārttikeya, Gaṇeśa, Śiva, and Brahmā in the surrounding shrines. ${ }^{94}$ In Rajan's assessment, the affiliation of the caves would have been predominately Vaișnava. ${ }^{95}$ This characterization does not acknowledge the three relief carvings depicting linga veneration, which Rajan does not mention in his report. One of these scenes appears clearly in a frieze in the entryway wall. The other two appear in a panel on the opposite wall. They are badly damaged; only one can still be seen clearly in a photograph [Figure 85].

\subsection{The Takli-Dhokeśvar Śaiva Caves}

In comparison to the caves at Bhokardan and Aurangabad, the excavation at Takli-Dhokeśvar ${ }^{96}$ can be properly classified as 'Śaiva' since religious life at the site was oriented around the linga shrine that occupies the center of the cave.

94 Rajan, Cave Temples of the Deccan, 164.

95 Rajan, Cave Temples of the Deccan, 163.

96 These caves are set up in the hills overlooking the Kalu River and reservoir a few kilometers north-east of the village of Takli, off of the Poona highway in the Ahmednagar District. 


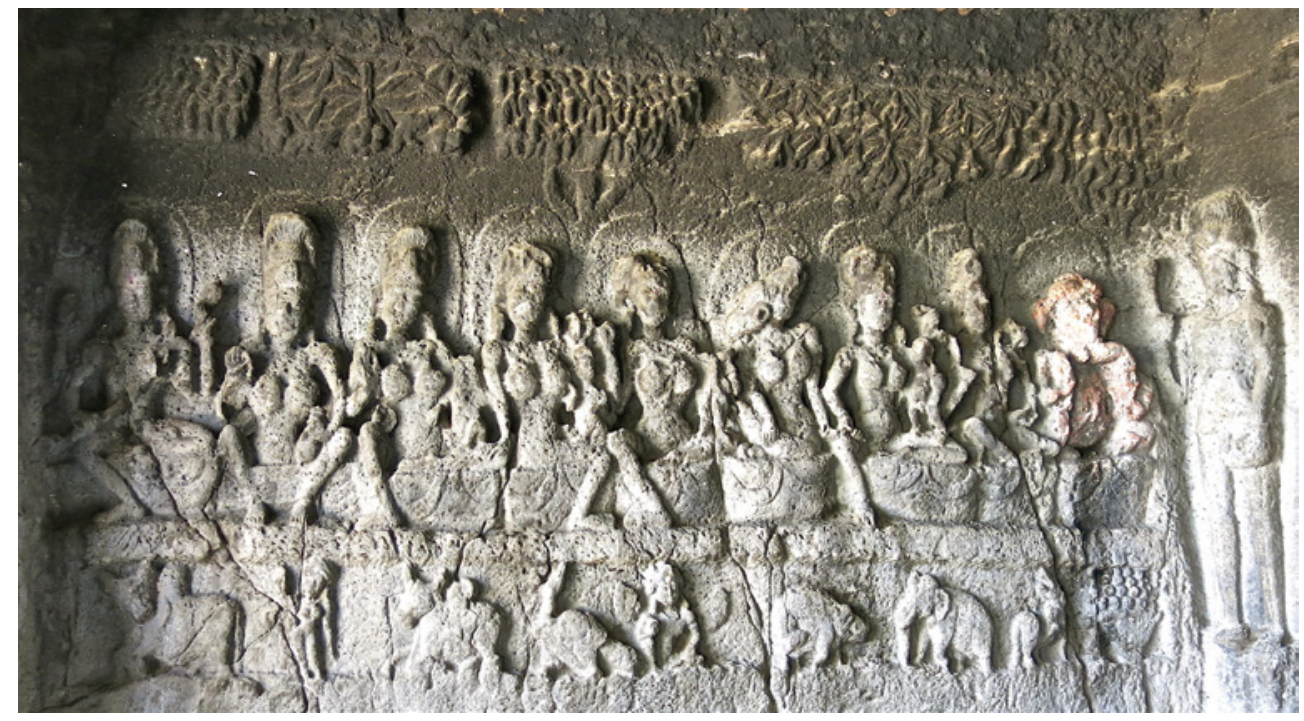

FIGURE 86 Takli-Dhokeśvar caves, Saptamātṛkā panel with Vīrabhadra and Gạ̣eśa

This site is interesting because we can still observe traces of the various religious concerns and values articulated within this space.

The cave opens to the east and is accessed via an entryway framed by sculptures of the river goddesses Gangā and Yamunā. The interior is dominated by a single linga shrine that is still in active use. In the interior entryway (mahamandapa), the north and south walls are adorned with sculpted panels. On the south side a large panel depicting the Mātrus-Brāhmī, Maheśvarī, Kaumarī, Vaiṣnavīi, Vārāhī, Aindrī, and Cāmuṇụā, each with her signature animal vehicle carved in the lower register - flanked by Vīrabhadra and Ganeśa [Figure 86]. The lush foliage and fruiting mango trees carved in the upper register of the panel and the children in their arms convey clearly their associations with fertility and prosperity. Their place of prominence in the mahamandapa indicates the important role these goddesses played in the devotional life of this site. The inclusion of the Mãtrs, could suggest royal patronage as some scholars have argued, but in my judgment, it is more likely that these powerful goddesses symbolize widespread concerns for fertility, prosperity, and protection that were not restricted to a particular class or social group. On the east-facing wall just adjacent the panel a skeletal figure is shown, perhaps Bhrngiritịi. Opposite the Mātrka panel, the north wall of the entrance shows an eight-armed image of Tāṇ deva Śiva.

The images to either side of the door guardians are not immediately recognizable. On the proper right, the stout seated figure, flanked by mālädharas, 


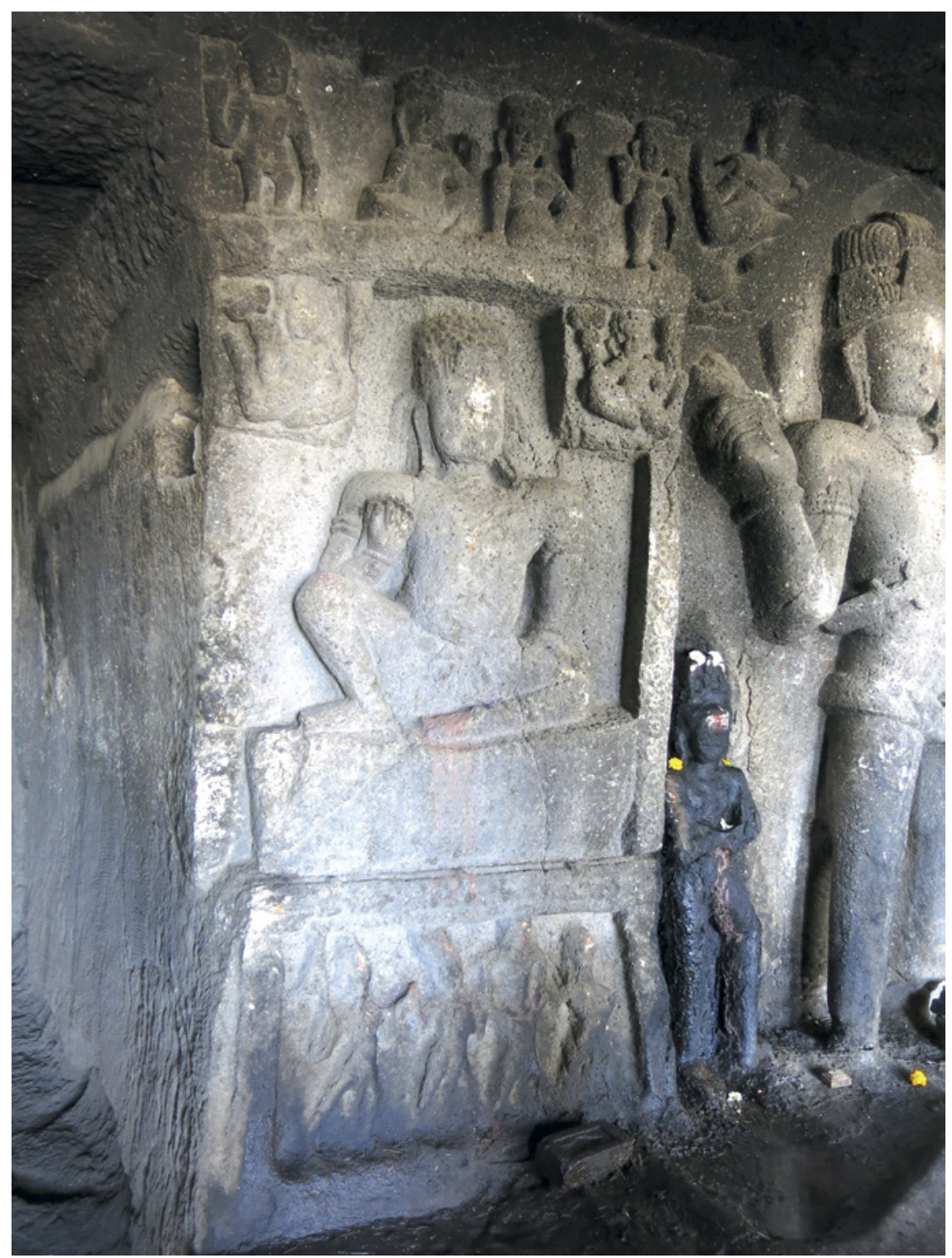

FIGURE 87

Takli-Dhokeśvar caves, nidhi figure with four small figures beneath

is carved over a niche containing four smaller figures [Figure 87]. The images are highly abraded and, as such, there are few visual clues with which we can reconstruct their identities. The seated figure has the right hand raised in what could have been a gesture of teaching. The presence of the four smaller figures below-their smaller stature and subordinate position are a cue that 
they could be devotees or attendants of the larger seated figure-could convey that the larger figure represents the charismatic and venerable persona of a guru. At the same time, the active postures of the attendant figures, which appear to be carrying things, do not resemble the meditative or devotional poses typically assumed by students in such tableaus depicting the teacher/disciple relationship. ${ }^{97}$ I think that this figure was intended as a nidhi, a figural embodiment of prosperity, richness, and the fecundity of the natural world. ${ }^{98}$ The stoutness of the figure and his seated posture does bear some resonance to images of Kubera, although the coin-purse and other defining attributes of this deity are missing. As a more generalized representation of some of the same ideals that Kubera represented, the decision to depict this nidhi figure in such close proximity to the linga shrine is an indication of the importance placed upon values of prosperity and fertility and a desire to articulate a clear association of these values with Śiva. ${ }^{99}$

The image on the right side of the shrine is also not easy to identify [Figure 88]. Commenting on the heavy bags the figure is carrying over the left shoulder, Rajan tentatively suggests that this figure could represent Kubera. If so, this would be an anomalous representation of this deity, whose mongoose moneybag is typically much smaller and held in one hand. In addition, the thin body of this figure does not connote wealth and prosperity, as does Kubera's large belly. As an alternative interpretation, I suggest this figure represents what is called today a Bhiśtịi, a professional water carrier, who traditionally transported water in large goat-skin bags. Often, two of these bags were strung together and carried over the shoulder in exactly the fashion shown in this sculpture. ${ }^{100}$ The image of this water bearer also gestures visually to the ritual

97 Compare the depictions of Lakulīśa with the four students surveyed in Chapter 6. See also Tamara Sears, "In the Gaze of the Guru: Shikshadana Scenes at Khajuraho," in Art, Icon, and Architecture in South Asia essays in honor of Dr. Devangana Desai, ed. A. Verghese and A.L. Dahmen-Dallapiccola (Delhi: Aryan Book International, 2015), 151-168.

98 For a discussion of the nidhi vis-à-vis comparable figures like yakșas in a Buddhist context see Claudin Bautze-Picron, "Nidhis and other Images of Richness and Fertility in Ajaṇțā," East and West $5^{2}$ (2002): 225-284.

99 It could be argued that a similar resonance is observed in the famous Mansar Śiva (Bakker, The Vākătakas, 149-151), which has been compared (even identified) as a nidhi and as a representation of Kubera. See Robert L. Brown, "Vākāțaka-Period Hindu Sculpture," in The Vākātaka Heritage. Indian Culture at the Crossroads, ed. Hans T. Bakker (Groningen: Egbert Forsten, 2004), 59-69.

100 The Takli water-bearer is comparable to figures, called simply 'carriers' by Bakker, found carved at multiple places on Kalinjar hill. I think the Kalinjar images may also refer to the kavad ritual. Bakker, The World of the Skandapurāna, 205-209. 


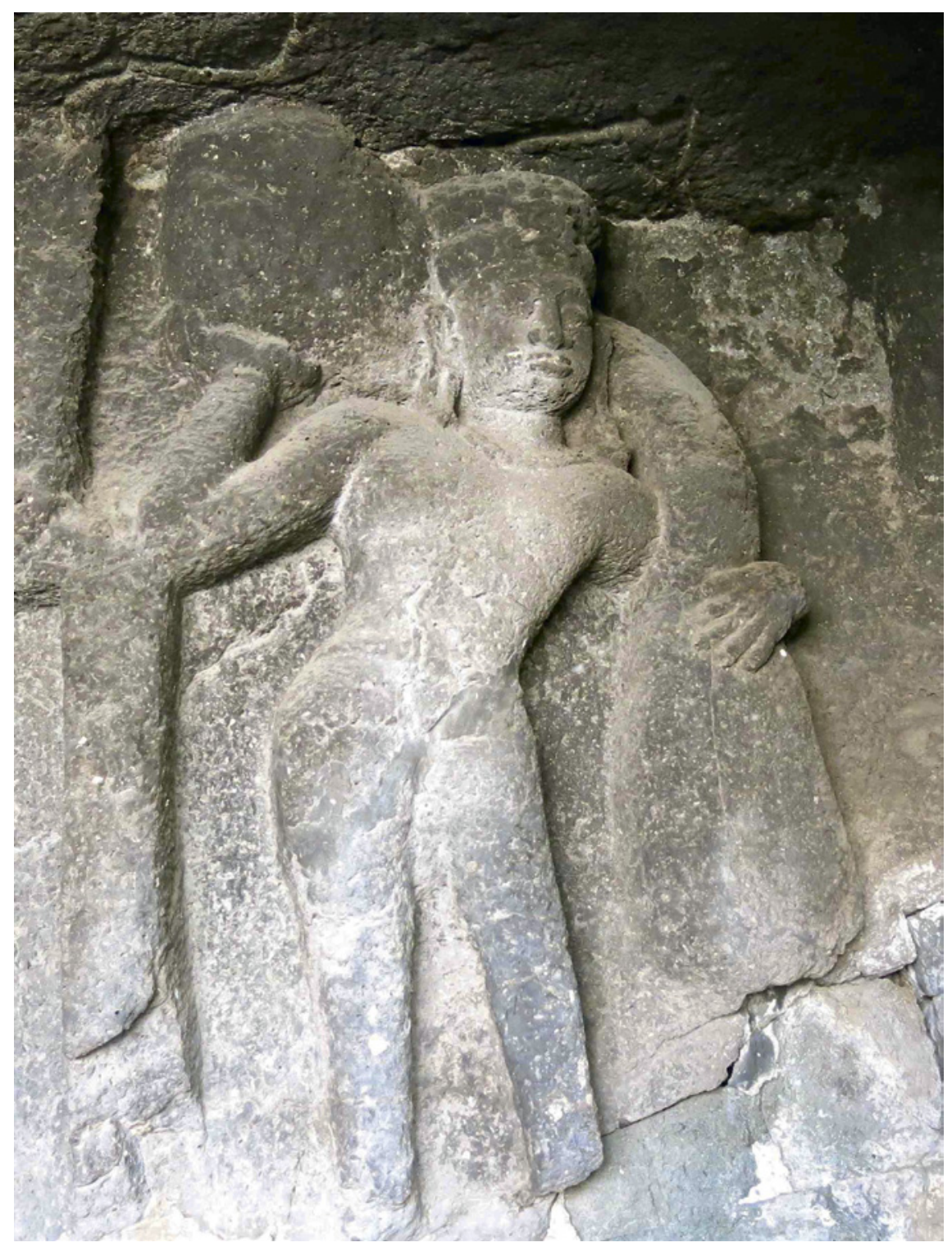

FIGURE 88 Takli-Dhokeśvar, Bhiśtī (water carrier) 


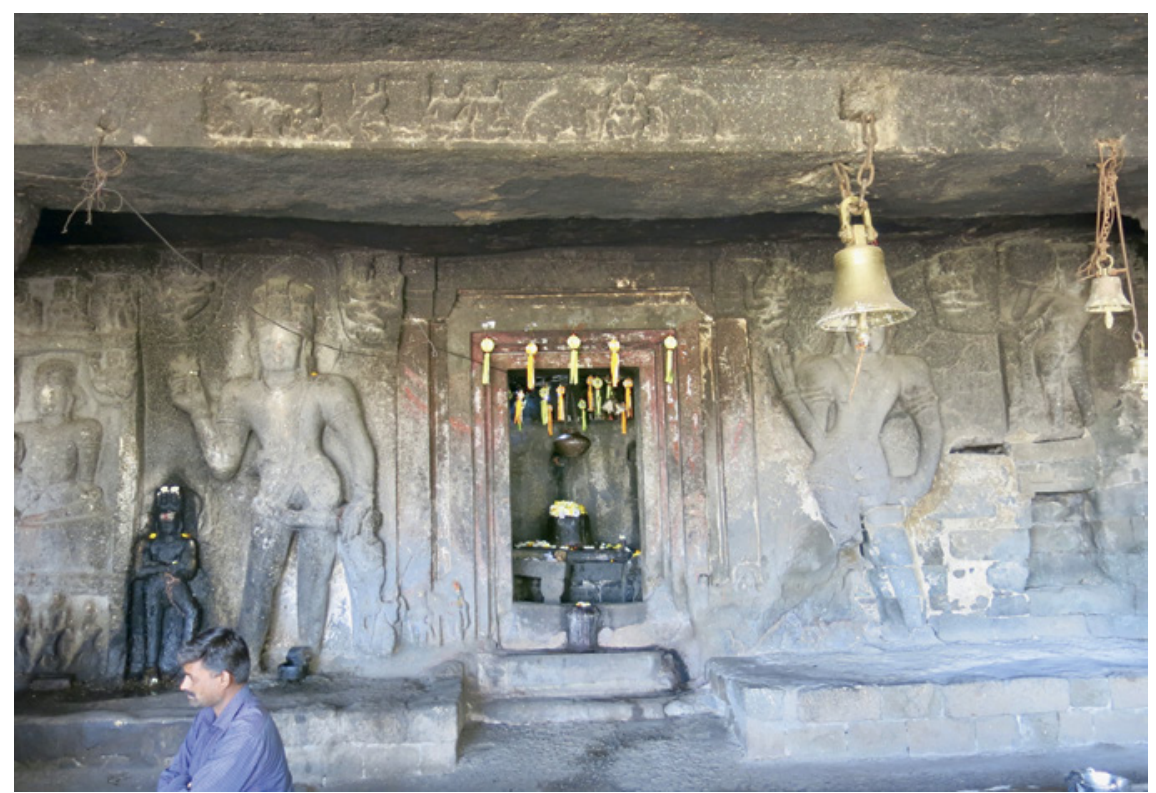

FIGURE 89 Takli-Dhokeśvar, linga shrine with framing guardians and triśūlapuruṣa

of kavad in which water is carried from sacred rivers, often at a long distance, and used to bathe the linga. ${ }^{101}$ The placement of the water carrier within the iconographic program at Takli would have been fitting considering the importance of the site as a major water collection facility. At short distance from the cave, channels were cut in the rock face to direct water that flows down from the hilltops in the rainy season into vast caverns where it is collected and stored beneath the excavated site [Figure 89].102 The presence of small, simply excavated caves to the south of the linga shrine accessed via carved footholds in the rock face could have been residential, a development that was perhaps also connected to the presence of water.

\section{5}

\section{Conclusions}

Analysis of the siting of Śaiva religious centers in the North Konkan supports the existence of strong ties between religious institutions and the dynamics of

\footnotetext{
101 On these rituals in Maharashtra see Anne Feldhaus, Water \& Womanhood (New York/ Oxford: Oxford University Press, 1995).

102 During my visit during the height of the dry season, the collection area was still quite full. The caretakers reported that this was consistently the case.
} 
regional economy and ruling powers, which I postulate to be evidence that, as with the Buddhist communities that preceded them, the growth of the Śaiva centers was conditioned by this cosmopolitan port polity. While the lack of epigraphic data from the North Konkan and the Deccan sites poses a significant challenge, this absence provides certain opportunities as well. It serves to redirect the scholarly gaze and to encourage us to consider these places not as the product of a particular dynasty, but as part of a much larger and diverse social landscape. When we consider the North Konkan sites within the larger region, it is not surprising that the monumental cave temples of Elephanta, Maṇapeśvar, and Jogeśvarī developed in such a commercially active and cosmopolitan area. Much like the urban melting pot of modern Mumbai, this region attracted people from across the subcontinent and beyond, provided religious specialists with ample opportunities for patronage, while furnishing highly skilled artisans to call these monumental centers into material form. And it was at these sites, where religious competition was the most intense and in which the religious landscape was most dense, that a Śaiva presence was articulated most distinctly in the iconographic program. And, in the case of Jogeśvarī, it is where we see the strongest evidence for a Pāśupata presence through the strategic placement of Lakulīsa images.

The patterns that characterize the North Konkan, however, do not emerge as strongly in the Deccan sites. The more modest Deccan caves serve as an illuminating contrast and illustrate the ways in which differences in regional geography, settlement patterns, economy, and politics conditioned the development of the religious landscape. The hinterland sites represent the polysemy of religious identity and accommodated a variety of religious concerns. While much more work is needed to flesh out the biographies of these sites, this brief survey initiates the process by showing that the Śaiva communities of the northwest Deccan may have developed in relative independence from the Konkan sites and in conversation with the regions further south.

The distinction that has emerged between the Konkan and Deccan sites also serves to delineate the borders of the Passupata landscape and the trajectory of the Pâśupata movement with a greater clarity. I interpret the presence of Lakulīśa images at Jogeśvarī as an indication of Pāśupata activity at the site. We might assume some Pāśupata presence at Manḍapeśvar based upon the single Lakulissa image, but here the traces become much fainter. The western Deccan sites I surveyed preserve no material traces of Pāśupata activity. Clearly the worship of Śiva around the Sahya Mountain took multiple forms and accommodated a wide range of religious values and concerns. Evidence of a specifically Pāśupata presence, however, indicates that the development of that particular religious network was oriented in the vicinity of the cosmopolitan economic centers. 